\title{
ANÁLISE DO DESEMPENHO DE HIDRO-EJETORES \\ FUNCIONANDO COMO BOMBA DE VÁCUO
}

EDUARDO FERRAZ DE OLIVEIRA

Orientador: Prof. Dr. Tarlei Arriel Botrel

Dissertação apresentada à Escola Superior de Agricultura "Luiz de Queiroz", da Universidade de São Paulo, para obtenção do título de Mestre em Agronomia, Área de Concentração: Irrigação e Drenagem. 
Ficha catalográfica preparada pela Seçăo de Livros da Divisao de Eiblioteca e Documentafáa - FCLQ/USF

Qliveira, Eduardo Ferraz de

Q48a Analise do desempento de hidra-ejetores funcionan

do como bomba de vácuo. Piracicaba, 1793. $65 p$.

Diss. (Mestre) - ESALQ

Bibliografia.

1. Eomba centrifuga 2. Eomba à vácuo 3. Hidro-ejetor - Desempento - Análise 4. Irrigaça - Equipamento I. Escola Superior de Agricultura Luiz de Gueiroz, Fi racicata

CDD $\quad 631.7$ 


\title{
ANÁLISE DO DESEMPENHO DE HIDRO-EJETORES \\ FUNCIONANDO COMO BOMBA DE VÁCUO
}

\author{
EDUARDO FERRAZ DE OLIVEIRA
}

Aprovado em: 14.12.1993

Comissão julgadora:

Prof. Dr. Tarlei Arriel Botrel

ESALQ/USP

Prof. Dr. Nilson Augusto Villa Nova

ESALQ/USP

Prof. Dr. Mario Benincasa

FCAV/UNESP

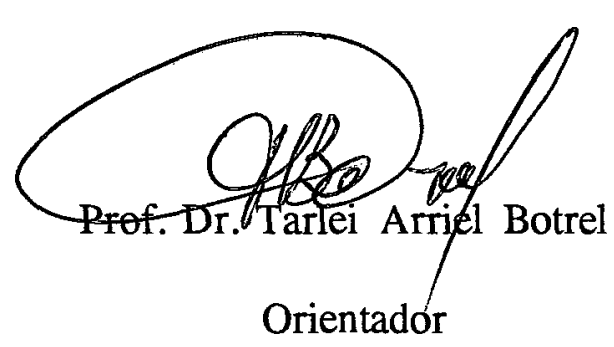




\section{SUMÁRIO}

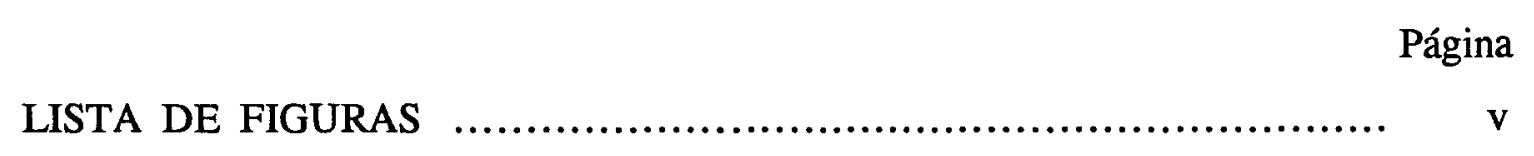

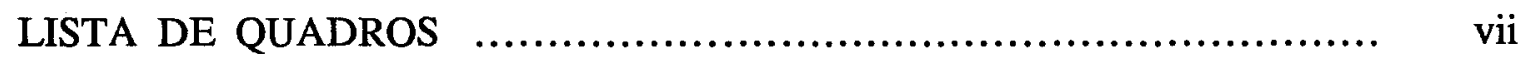

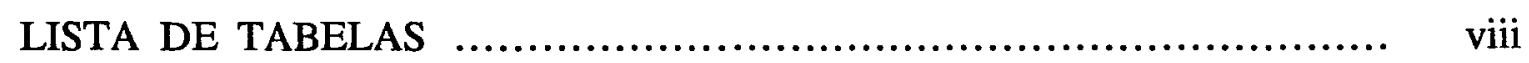

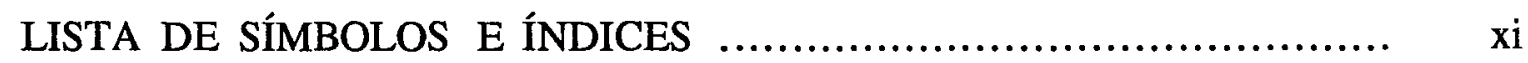

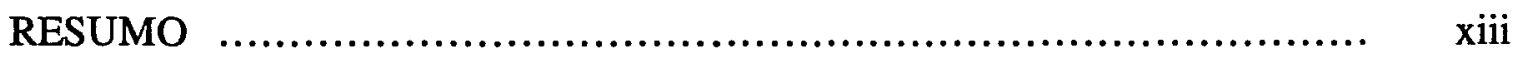

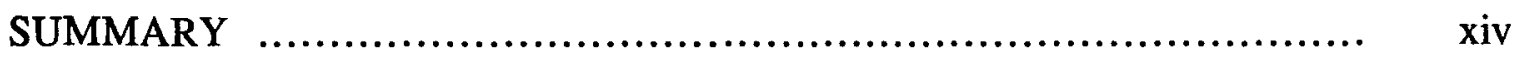

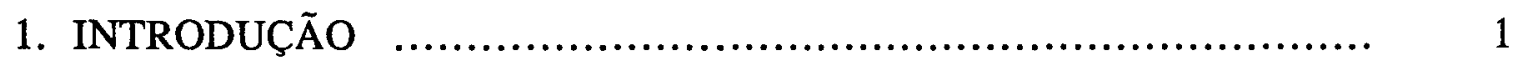

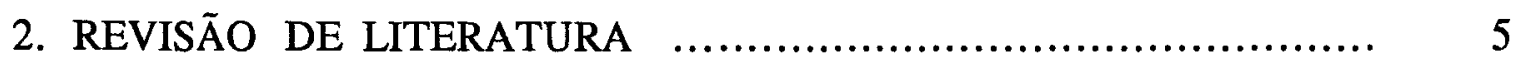

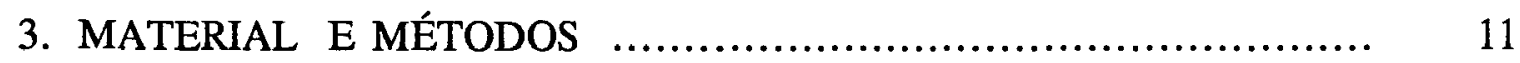

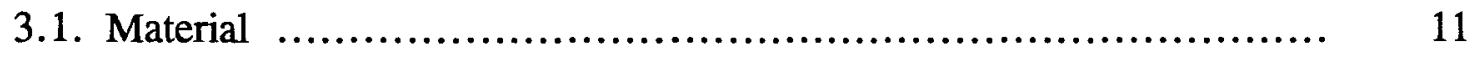

3.1.1. Bombas Centrífugas ...................................... 11

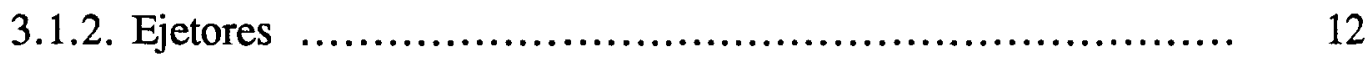

3.1.3. Medidores de Vazão .......................................... 15

3.1.3.1. Medidor de Vazão Magnético Indutivo (CONAUT) 15

3.1.3.2. Tubo de Venturi .................................. 15

3.1.3.3. Medidores para gás "LAO" ...................... 16 
Página

3.1.3.4. Anemômetro ........................................ 16

3.1.4. Medidores de Pressão ............................................ 16

3.2. Métodos ............................................................... 17

3.2.1. Esquemas de Montagem dos Equipamentos ................ 17

3.2.2. Parâmetros de Desempenho .................................. 17

3.2.2.1. Curva Vazão de Sucção Versus Pressão de Sucção 26

3.2.2.2. Rendimento $(\mathrm{n})$.................................. 28

4. RESULTADOS E DISCUSSÃO ….................................... 32

4.1. Dos Ensaios com o Ejetor 1 succionando Ar .................... 32

4.2. Dos Ensaios com o Ejetor 1 succionando Água ................... 38

4.3. Dos Ensaios com o Ejetor 2 succionando Ar ...................... 46

4.4. Dos Ensaios com o Ejetor 2 succionando Água ................... 53

4.5. Considerações Gerais ........................................... 62

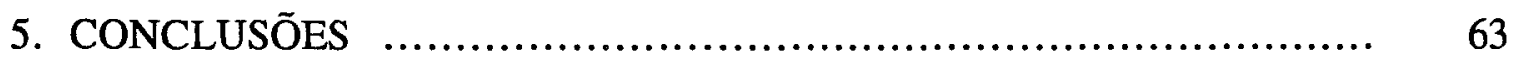

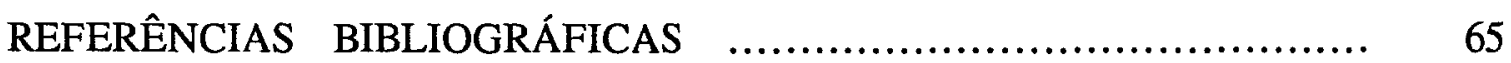




\section{LISTA DE FIGURAS}

Página

Figura 1 Esquema funcional de um Ejetor ............................. 6

Figura 2 Princípio de funcionamento de um Ejetor .................... 7

Figura 3 Corte longitudinal do Ejetor 1 ............................. 13

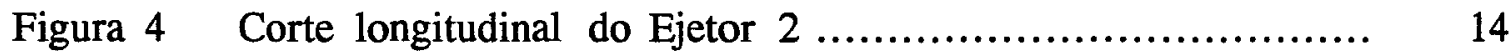

Figura 5 Montagem para ensaios com o Ejetor 1 succionando ar ....... 18

Figura 6 Montagem para ensaios com o Ejetor 2 succionando ar ....... 19

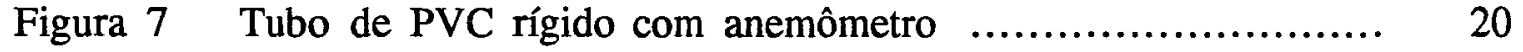

Figura 8 Montagem para ensaios com o Ejetor 2 succionando água .... 21

Figura 9 Esquema de montagem do dispositivo com o Ejetor 1 e a bomba MARK BDS9 para succionar ar ..................... 22

Figura 10 Esquema de montagem do dispositivo com o Ejetor 1 e a bomba MARK BDS9 para succionar água .................. 23

Figura 11 Esquema de montagem do dispositivo com o Ejetor 2 e a bomba KSB-WL 80/5 para succionar ar ..................... 24

Figura 12 Esquema de montagem do dispositivo com o Ejetor 2 e a bomba KSB-WL 80/5 para succionar água .................. 25

Figura 13 Corte longitudinal de um Ejetor .............................. 28

Figura 14 Vazão de sucção de ar em relação à pressão absoluta de sucção para o Ejetor 1 sob as pressões de alimentação de $10,20,30,40,50,60$ e 70 m.c.a.

Figura 15 Rendimento em relação à pressão absoluta de sucção de ar para o Ejetor 1 sob as pressões de alimentação de $10,20,30,40,50,60$ e 70 m.c.a.

Figura 16 Vazão de sucção de água em relação à pressão absoluta de sucção para o Ejetor 1 sob as pressões de alimentação 
Página

de $10,20,30,40,50,60$ e 70 m.c.a............................ 45

Figura 17 Rendimento em relação à pressão absoluta de sucção de água para o Ejetor 1 sob as pressões de alimentação de $10,20,30,40,50,60$ e 70 m.c.a. ...............................

Figura 18 Vazão de sucção de ar em relação à pressão absoluta de sucção para o Ejetor 2 sob as pressões de alimentação de $10,20,30,40$ e 50 m.c.a.

Figura 19 Rendimento em relação à pressão absoluta de sucção de ar para o Ejetor 2 sob as pressões de alimentação de $10,20,30,40$ e 50 m.c.a.

Figura 20 Vazão de sucção de água em relação à pressão absoluta de sucção para o Ejetor 2 sob as pressões de alimentação de $10,20,30,40$ e 50 m.c.a

Figura 21 Rendimento em relação à pressão absoluta de sucção de água para o Ejetor 2 sob as pressões de alimentação de $10,20,30,40$ e 50 m.c.a. 


\section{LISTA DE QUADROS}

Página

Quadro 1 Características das Bombas Centrífugas ......................... 11

Quadro 2 Características dos Ejetores ................................. 12 


\section{LISTA DE TABELAS}

Página

Tabela 1 Pressão absoluta de sucção, vazão de sucção, vazão de alimentação e rendimento para o Ejetor 1, succionando ar, à pressão de alimentação de 10 m.c.a.....................

Tabela 2 Pressão absoluta de sucção, vazão de sucção, vazão de alimentação e rendimento para o Ejetor 1, succionando ar, à pressão de alimentação de 20 m.c.a......................

Tabela 3 Pressão absoluta de sucção, vazão de sucção, vazão de alimentação e rendimento para o Ejetor 1, succionando ar, à pressão de alimentação de 30 m.c.a....................

Tabela 4 Pressão absoluta de sucção, vazão de sucção, vazão de alimentação e rendimento para o Ejetor 1, succionando ar, à pressão de alimentação de 40 m.c.a. .....................

Tabela 5 Pressão absoluta de sucção, vazão de sucção, vazão de alimentação e rendimento para o Ejetor 1, succionando ar, à pressão de alimentação de 50 m.c.a......................

Tabela 6 Pressão absoluta de sucção, vazão de sucção, vazão de alimentação e rendimento para o Ejetor 1, succionando ar, à pressão de alimentação de 60 m.c.a.......................

Tabela 7 Pressão absoluta de sucção, vazão de sucção, vazão de alimentação e rendimento para o Ejetor 1, succionando ar, à pressão de alimentação de 70 m.c.a......................

Tabela 8 Valores dos parâmetros de ajuste da vazão de ar succionado versus pressão absoluta de sucção para o Ejetor 1 .....

Tabela 9 Pressão absoluta de sucção, vazão de sucção, vazão de alimentação e rendimento para o Ejetor 1, succionando 
Página

água, à pressão de alimentação de 10 m.c.a.................... 40

Tabela 10 Pressão absoluta de sucção, vazão de sucção, vazão de alimentação e rendimento para o Ejetor 1, succionando água, à pressão de alimentação de 20 m.c.a.................... 40

Tabela 11 Pressão absoluta de sucção, vazão de sucção, vazão de alimentação e rendimento para o Ejetor 1 , succionando água, à pressão de alimentação de 30 m.c.a................... 41

Tabela 12 Pressão absoluta de sucção, vazão de sucção, vazão de alimentação e rendimento para o Ejetor 1, succionando água, à pressão de alimentação de 40 m.c.a................... 41

Tabela 13 Pressão absoluta de sucção, vazão de sucção, vazão de alimentação e rendimento para o Ejetor 1 , succionando água, à pressão de alimentação de 50 m.c.a................... 42

Tabela 14 Pressão absoluta de sucção, vazão de sucção, vazão de alimentação e rendimento para o Ejetor 1 , succionando água, à pressão de alimentação de 60 m.c.a....................

Tabela 15 Pressão absoluta de sucção, vazão de sucção, vazão de alimentação e rendimento para o Ejetor 1, succionando água, à pressão de alimentação de 70 m.c.a....................

Tabela 16 Valores dos parâmetros de ajuste da vazão de água succionada versus pressão absoluta de suç̧ão para o Ejetor 1 ......................................................

Tabela 17 Pressão absoluta de sucção, vazão de suç̧ão, vazão de alimentação e rendimento para o Ejetor 2, succionando ar, à pressão de alimentação de 10 m.c.a.

Tabela 18 Pressão absoluta de sucção, vazão de sucção, vazão de alimentação e rendimento para o Ejetor 2 , succionando ar, à pressão de alimentação de 20 m.c.a...................... 
Página

Tabela 19 Pressão absoluta de sucção, vazão de sucção, vazão de alimentação e rendimento para o Ejetor 2, succionando ar, à pressão de alimentação de 30 m.c.a

Tabela 20 Pressão absoluta de sucção, vazão de sucção, vazão de alimentação e rendimento para o Ejetor 2, succionando ar, à pressão de alimentação de 40 m.c.a.

Tabela 21 Pressão absoluta de sucção, vazão de sucção, vazão de alimentação e rendimento para o Ejetor 2, succionando ar, à pressão de alimentação de 50 m.c.a

Tabela 22 Valores dos parâmetros de ajuste da vazão de ar succionado versus pressão absoluta de sucção para o Ejetor 2 ....

Tabela 23 Pressão absoluta de sucção, vazão de sucção, vazão de alimentação e rendimento para o Ejetor 2, succionando água, à pressão de alimentação de 10 m.c.a.

Tabela 24 Pressão absoluta de sucção, vazão de sucção, vazão de alimentação e rendimento para o Ejetor 2, succionando água, à pressão de alimentação de 20 m.c.a.

Tabela 25 Pressão absoluta de sucção, vazão de sucção, vazão de alimentação e rendimento para o Ejetor 2, succionando água, à pressão de alimentação de 30 m.c.a. ..................

Tabela 26 Pressão absoluta de sucção, vazão de sucção, vazão de alimentação e rendimento para o Ejetor 2, succionando água, à pressão de alimentação de 40 m.c.a...................

Tabela 27 Pressão absoluta de sucção, vazão de sucção, vazão de alimentação e rendimento para o Ejetor 2, succionando água, à pressão de alimentação de 50 m.c.a...................

Tabela 28 Valores dos parâmetros de ajuste da vazão de água succionada versus pressão absoluta de sucção para o Ejetor 2 


\section{LISTA DE SÍMBOLOS E ÍNDICES}

E - energia mecânica total por unidade de peso líquido e é designada por carga total [m]

Z - cota geométrica em relação a um plano horizontal de referência e representa a energia de posição da unidade de peso líquido [m]

$\mathbf{P} / \gamma \quad$ - energia de pressão da unidade de peso líquido designada por altura piezométrica [m]

$\mathrm{V}^{2} / 2 \mathrm{~g}$ - energia cinética por unidade de peso líquido designada por altura cinética [m]

NPSH - Net Positive Suction Head (altura piezométrica útil absoluta na aspiração) [m]

m - relação entre áreas (s/S) ou diâmetros (d/D). É uma característica do ejetor $(m<1) \quad[-]$

$\mathrm{m}_{\mathrm{i}} \quad$ - massa do fluído $[\mathrm{Kg}]$

m.c.a. - metro de coluna de água [m]

$H_{\mathrm{i}} \quad$ - nível energético (pressão) [m.c.l.]

$\mathrm{V}_{\mathrm{i}}$ - velocidade do fluído $[\mathrm{m} / \mathrm{s}]$

$\mathrm{Q}_{\mathrm{i}}$ - vazão do fluído $\left[\mathrm{m}^{3} / \mathrm{s}\right]$

H - altura líquida de elevação [m]

h - altura líquida motriz [m]

$\mu \quad-\mathrm{H} / \mathrm{h} \quad[-]$

$\mathrm{Q}_{2} \quad$ - vazão de elevação $\left[\mathrm{m}^{3} / \mathrm{s}\right]$

$\mathrm{Q}_{1}$ - vazão motriz $\left[\mathrm{m}^{3} / \mathrm{s}\right]$

$\begin{array}{lll}\delta & -\mathrm{Q}_{2} / \mathrm{Q}_{1} & {[-]}\end{array}$

n $\quad$ - rendimento do ejetor $(\mu . \delta)$ [-]

$\mathrm{N} \quad$ - potência teórica [C.V.] 
$\mathrm{D}_{\mathrm{i}}$ e $\mathrm{d}_{\mathrm{i}}$ - diâmetro [m]

$\mathrm{L}_{\mathrm{i}}$ - comprimento [m]

$\mathrm{A}_{\mathrm{i}} \quad$ - área $\left[\mathrm{m}^{2}\right]$

K - constantes diversas [-]

$\theta \quad$ - volume $\left[\mathrm{m}^{3}\right]$ 


\title{
ANÁLISE DO DESEMPENHO DE HIDRO-EJETORES FUNCIONANDO \\ COMO BOMBA DE VÁCUO
}

\author{
Autor: EDUARDO FERRAZ DE OLIVEIRA \\ Orientador: PROF. DR. TARLEI ARRIEL BOTREL
}

\section{RESUMO}

A escorva de grandes bombas centrífugas, destinadas a condução ou elevação mecânica da água e instaladas sob condições de sucção negativa, tem sido realizada com o emprego de ejetores, através da criação de vácuo na canalização de aspiração e na própria bomba.

Nem sempre, porém, se emprega o ejetor adequado para a realização desse trabalho, em virtude da escassez de informações e dados técnicos a respeito.

A fim de contribuir para a solução desse problema, procurou-se avaliar o desempenho de aparelhos a jato acionados hidráulicamente, e realizando o trabalho de bomba de vácuo. Para tal, conduziram-se ensaios com dois tipos de hidro-ejetores, disponíveis no mercado, com parâmetros característicos $\mathrm{m}=0,35$ e $\mathrm{m}=0,52$, respectivamente, alimentados, cada qual, por uma bomba centrífuga, buscando conhecer os volumes de ar e de água arrastados, os rendimentos desses ejetores, a relação vazão de sucção/pressão de suç̧ão, para as diversas pressões e vazões de alimentação, préviamente estipuladas.

Os resultados obtidos permitiram estabelecer conhecimentos técnicos esclarecedores a respeito do funcionamento de tais dispositivos, possibilitando uma escolha apropriada para os seus diferentes empregos, bem como, as condições ideais de operação.

Para avaliação do rendimento dos ejetores estudados foi deduzida a Equação 21, que se mostrou adequada em todas as condições de ensaio. 


\title{
ANALYSIS OF THE HYDRO-EJECTORS PERFORMANCE FUNCTIONING AS VACUUM PUMPS
}

\author{
Author: EDUARDO FERRAZ DE OLIVEIRA
} Adviser: PROF. DR. TARLEI ARRIEL BOTREL

\section{SUMMARY}

The primer of big centrifugal pumps, designed to water conducting or water mechanical elevation and installed under conditions of negative suction has been accomplished with the use of ejectors through the creation of vacuum in the system of pipelines of suction stroke and in the pump itself.

The adequate ejector is not always used in carrying out this work due to the lack of information and technical data about it.

In order to contribute to the solution of this problem it was evaluated the performance of jacto machines driven hydraulically and doing the work of the vacuum pump. For this purpose, tests were made with two types of hydro-ejectors available in the market with characteristic parameters $\mathrm{m}=0,35$ and $\mathrm{m}=0,52$ respectively, jed by a centrifugal pump seeking for the volumes of air and water dragged, the efficiency of these ejectors, the relation suction flowing/suction pressure for several pressures and feeding flowing, previously established.

The obtained results permit to establish clarifying technical knowledge about the performance of such devices and making possible an appropriate choice to their different applications as well as ideal operating conditions.

To the valuation of the ejectors efficiency, the Equation 21 was deduced and it has been adequate in all the testing conditions. 


\section{INTRODUÇÃO}

A questão de como se proceder para transportar água à curtas, médias e longas distâncias e ou elevações, desde o início da civilização tem sido uma constante preocupação do homem, o que deu origem aos estudos e construção de máquinas motrizes e elevatórias, de potências e rendimentos os mais variáveis.

CARLIER (1968), com base na conhecida equação fundamental de energia existente nas massas fluídas em movimento

$$
E=Z+\frac{P}{\gamma}+\frac{V^{2}}{2 g}
$$

considera que é possível distinguir as máquinas elevatórias, simplesmente pelo seu desempenho particular a cada um dos três termos do segundo membro (posição, pressão e velocidade) e propõe a seguinte classificação, que corresponde, aproximadamente, a ordem cronológica em que elas foram inventadas e utilizadas.

a) Máquinas do $1^{\circ}$ Tipo - São aquelas cuja elevação mecânica do líquido resulta, essencialmente, de uma variação da cota altimétrica $\mathrm{Z}$ da massa líquida considerada, sendo que a pressão e a velocidade variam relativamente pouco ou não se alteram. Essas máquinas assumem, construtivamente, uma altura igual a altura de elevação, operam pelo enchimento contínuo de recipientes em movimento ou por retenção da água por capilaridade e são, geralmente, as mais antigas que se tem conhecimento (Nora Chinesa, Parafuso de Arquimedes, Sistema de Correntes, etc.). 
b) Máquinas do $2^{\circ}$ Tipo - São aquelas cuja elevação mecânica do líquido resulta, sobretudo, de um aumento de pressão da massa líquida. Trata-se de máquinas, organicamente, mais complicadas, porém de dimensões muito reduzidas, quando comparadas à altura de elevação. São apropriadamente chamadas "bombas" e incluem-se aqui as de pistão, que podem ser alternativas, quando o movimento do pistão é retilíneo, rotativas e semi-rotativas, para movimento circular do pistão, no caso, rotor.

c) Máquinas do $3^{\circ}$ Tipo - São aquelas cuja elevação mecânica do líquido resulta, principalmente, de uma variação da velocidade de escoamento, imediatamente transformada em pressão. Pertencem a este grupo o carneiro hidráulico, os aparelhos a jato e as bombas centrífugas, estas últimas, as mais largamente empregadas por apresentarem uma grande variação do campo de trabalho (altura manométrica e vazão), maior número de velocidades de operação, pequenas dimensões construtivas e fácil manutenção.

Os aparelhos a jato, escopo principal deste trabalho, são definidos, segundo TROSKOLANSKI (1977), como um dispositivo apropriado para, simultaneamente, aspirar e recalcar um fluído (líquido, gás ou vapor) ou uma mistura fluído-sólido, por aplicação prática do fenômeno de Venturi, utilizando um órgão de restrição secional à passagem da corrente fluída, alimentado por um outro fluído qualquer, denominado fluído primário ou fluído motor.

Ainda, segundo o citado autor, os aparelhos a jato se dividem, fundamentalmente, em dois grupos: ejetores e injetores. Os ejetores se prestam para aspirar um fluído de um local sob pressão qualquer e recalcá-lo para outro local sujeito à pressão atmosférica ou ligeiramente superior. Os injetores, ao contrário, são empregados para recalcar um fluído para um local sujeito a uma pressão superior à pressão atmosférica.

De acordo com o fluído que alimenta o órgão de restrição, os aparelhos a jato se dividem em: a) aparelhos a jato primário de líquido (geralmente água); b) aparelhos a jato primário de gás, e c) aparelhos a jato primário de vapor. 
O ejetor consta, em essência, de três segmentos sequenciais de formas cônica-convergente, cilíndrica e cônica-divergente, sendo que na porção cilíndrica está inserido um tubo aspirador.

O fluído motor que vai produzir a sucção desejada, ao atravessar o ejetor, no sentido bocal convergente para o divergente, atinge na seção cilíndrica, que é a de menor área, velocidade máxima e, por conseguinte, em decorrência da conservação de energia, a pressão abaixa. Com esta redução de pressão é criada no tubo aspirador uma condição de pressão inferior à pressão reinante externamente, provocando, conseqüentemente, o arraste de fluído para o interior do ejetor.

Os ejetores pelas vantagens que apresentam, como a ausência de elementos móveis, simplicidade de construção, dispensa de lubrificação, rapidez para ser colocado em serviço e uma gama razoável de vazões, estão, cada vez mais, de uso difundido nos domínios das técnicas e da indústria.

Assim é que o princípio de conservação da energia tem sido utilizado em carburadores, embaladores a vácuo, recipientes de instalações industriais de secagem, certos condensadores de vapor, na evacuação de água de esgoto, na exaustão de gases nocivos, na drenagem de áreas inundadas, no bombeamento de poços profundos, etc.

Também nos sistemas de elevação mecânica de água por intermédio de grandes conjuntos de bombeamento, instalados em condiçoes de sucção negativa com $\mathrm{NPSH}_{\mathrm{d}}$ superior ao $\mathrm{NPSH}_{\mathrm{r}}$, torna-se necessário, inicialmente, o preparo da bomba para o seu funcionamento, procedendo-se a substituição do ar, contido no seu interior e na canalização de sucção, pela água, operação essa conhecida como escorva e que, frequentemente, é realizada com o emprego de alguns tipos de ejetores disponíveis no comércio.

Ocorre, porém, na prática, situações em que a escolha desses ejetores para a operação de escorva de bombas se dá de forma empírica, em virtude da inexistência de informações detalhadas a seu respeito. 
Procurando dar subsídios aos projetistas e interessados nesses tipos de ejetores que funcionam como bomba de vácuo, no presente trabalho foram realizados vinte e quatro ensaios de laboratório, com dois tipos de ejetores $(\mathrm{m}=$ 0,35 e $\mathrm{m}=0,52$ ), encontrados no mercado, visando estabelecer as condições de pressão e de vazão da água de alimentação que possibilitem a adução de maior volume de ar ou de água, a uma dada pressão de sucção. 


\section{REVISÃO DE LITERATURA}

DANIEL BERNOULLI, em 1738, formulou a lei principal do movimento dos líquidos, estabelecendo a equação fundamental, mais tarde chamada de Equação de BERNOULLI, que relaciona, entre si, as energias de velocidade, de pressão e de posição, evidenciando o princípio da conservação de energia.

A Equação de BERNOULLI, constitui-se em um instrumento fundamental da hidrodinâmica e, como tal, permite a solução de inúmeros problemas de ordem prática. Um exemplo da sua aplicação é o emprego de ejetores funcionando como bomba de vácuo.

Diversos trabalhos teóricos e experimentais têm sido desenvolvidos por pesquisadores sôbre o fenômeno da ejeção, buscando melhor compreensão sobre as técnicas para dimensionamento dos ejetores, particularmente, funcionando em série com bombas centrífugas.

A aplicação ampla de bomba-ejetor é de desenvolvimento relativamente recente e suas características, possibilidades e limitações, não são conhecidas de forma tão geral como as de outros tipos de bombas.

Atualmente é freqüente $o$ uso de ejetores em conjunto com bombas centrífugas ou de outros tipos, para a extração de água em poços profundos. Como a altura geométrica de sucção dessas bombas está limitada pelas pressões de vapor e atmosférica, em condiçoes de profundidade superior a esse limite utiliza-se um ejetor para transmitir à massa líquida em movimento $\left(\mathrm{m}_{1}+\mathrm{m}_{2}\right)$ uma parcela de energia suficientemente grande, que irá garantir o funcionamento da bomba sem ocorrência de cavitação.

PETERS (1959), explica o princípio de funcionamento de um ejetor utilizando-se da Figura 1, que representa a vazão da massa $\mathrm{m}_{1}$ de fluído, de nível 
energético $\mathrm{H}_{1}$ (pressão) atravessando um bocal $\mathrm{B}$, em regime de escoamento permanente. Parte da energia desse jato é cedida, principalmente, na câmara de mistura $M$ à vazão de fluído $m_{2}$ que atravessa o bocal $S$, inicialmente num nível energético $\mathrm{H}_{2}$, mais baixo que $\mathrm{H}_{1}$. Na saída da câmara $M$, as duas massas misturadas $\left(m_{1}+m_{2}\right)$ têm quase a mesma velocidade $V_{3}$ sob o nível energético $H_{3}$. A velocidade $V_{3}$ é reduzida no difusor $D$ para $o$ valor $V_{3}$ e, na saída do ejetor, a massa $m_{3}=m_{1}+m_{2}$ assume o nível energético $H_{3}$.

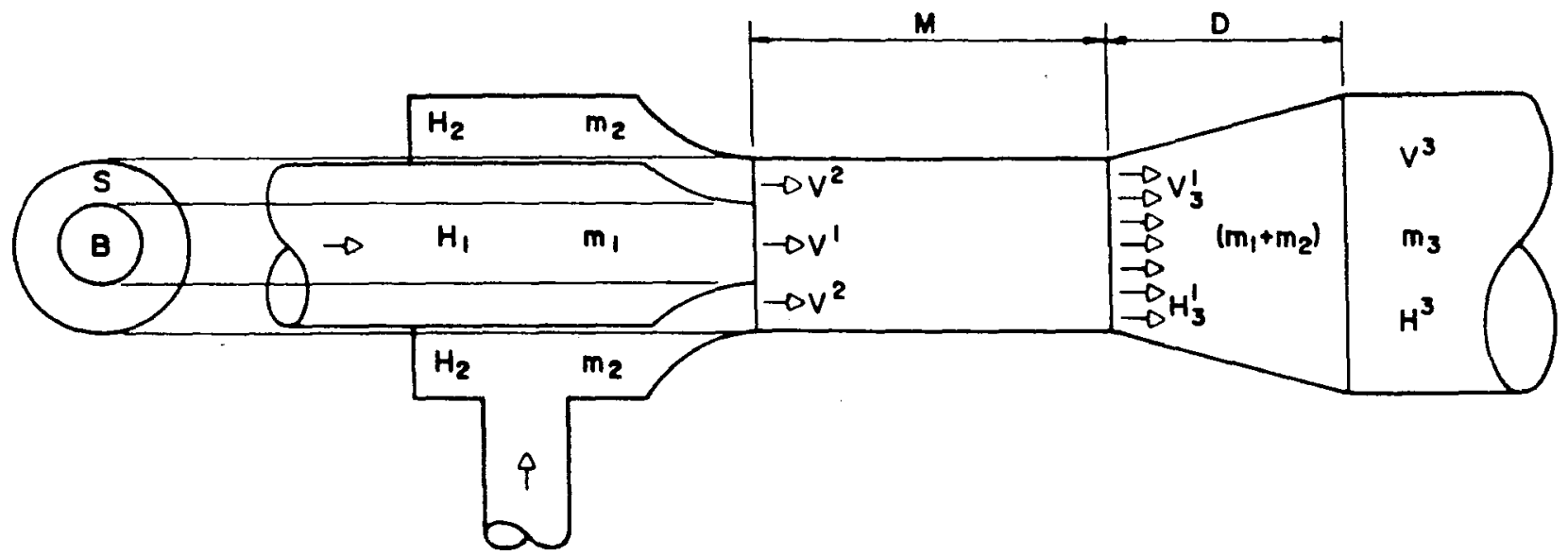

Figura 1 - Esquema funcional de um Ejetor

Tendo em vista a Figura 2, CARLIER (1968) procurou demonstrar o princípio de funcionamento de um ejetor sob carga constante. Observa-se que o fluído motor (água) ao se deslocar do nível superior RS até o nível PQ, com desnível $h$ e vazão $Q_{1}$, produz a elevação $H$ de uma vazão de água $Q_{2}$, do nível inferior $\mathrm{MN}$ até aquele mesmo nível $\mathrm{PQ}$. 


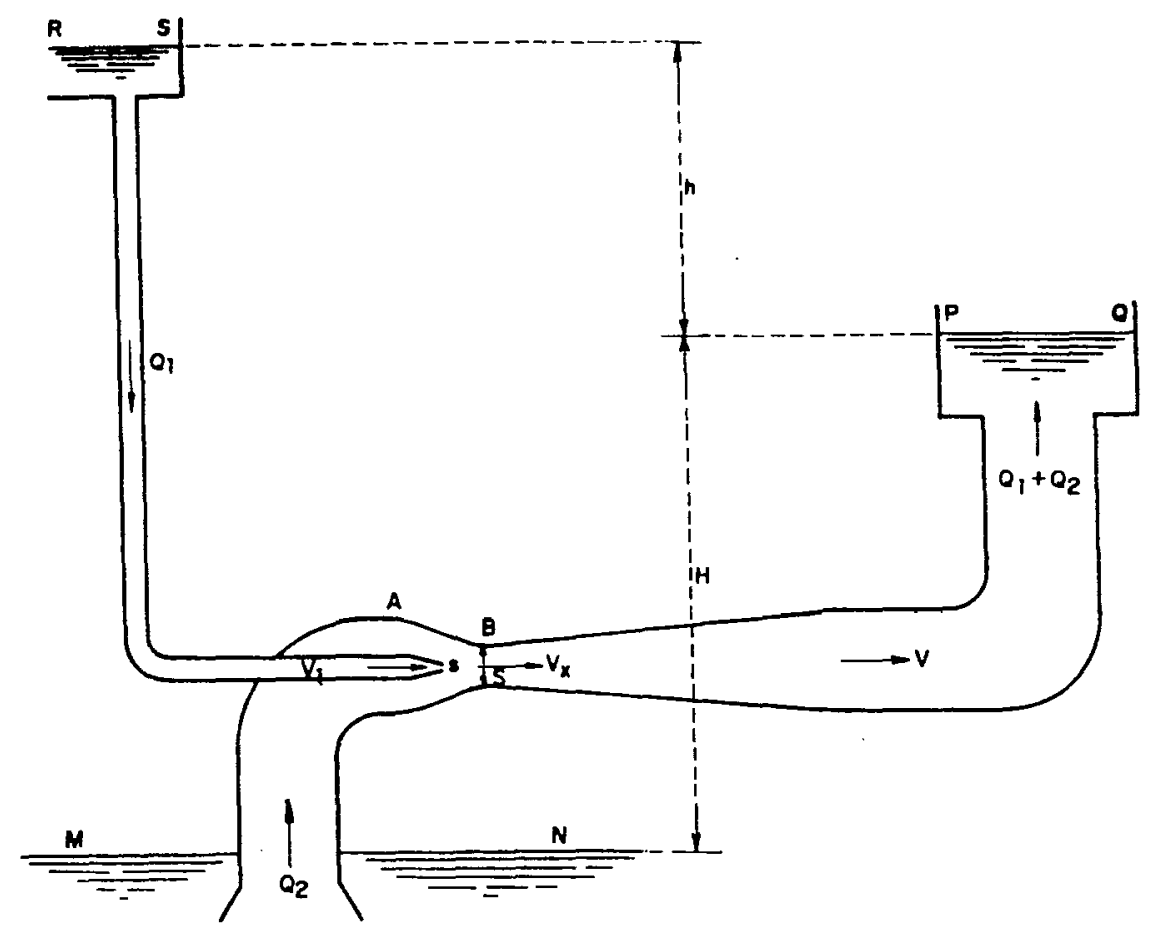

Figura 2 - Princípio de funcionamento de um Ejetor sob carga constante.

O funcionamento desses aparelhos a jato se baseia no fato de que a diminuição, mesmo tumultuada ou turbulenta, de uma velocidade $V_{1}$ a uma velocidade $V_{x}$, produz, consequentemente, um aumento de pressão. Mas, enquanto que uma diminuição progressiva de velocidade produzirá um aumento de pressão correspondente à totalidade da diferença das alturas representantivas das velocidades $\left(\frac{\mathrm{V}_{1}^{2}}{2 \mathrm{~g}}-\frac{\mathrm{V}_{\mathrm{r}}^{2}}{2 \mathrm{~g}}\right)$, a diminuição tumultuosa causará um aumento menor e a diferença é dissipada na massa líquida sob a forma de calor.

Para reduzir essas perdas adapta-se um bocal divergente, depois de B, no sentido da corrente fluída, a fim de restabelecer progressivamente a velocidade de $V_{x}$ para $V$ e recuperar, ao máximo possível, a pressão resultante dessa complementar diminuição de velocidade. Com efeito, nos perfis estudados o rendimento desse bocal jamais alcança o valor unitário e permanece compreendido entre 0,7 e 0,85 . 
Acrescenta ainda CARLIER que o rendimento global do ejetor, admitindo comuns o fluído motor e o de sucção, é dado por:

$$
\mathrm{n}=\frac{\mathrm{Q}_{2} \mathrm{H}}{\mathrm{Q}_{1} \mathrm{~h}}=\mu \delta
$$

E que as curvas características de $\mathrm{H}\left(\mathrm{Q}_{2}\right)$ e ${ }^{\mathrm{n}}\left(\mathrm{Q}_{2}\right)$, sob uma carga motriz (h) constante, são semelhantes àquelas das bombas centrífugas, assim como, também o rendimento é sempre pequeno, no máximo 0,3 .

Para um dado ejetor, o rendimento máximo é obtido para o valor máximo do produto $\mu . \delta$, isto é, para $\mu=\frac{\mu_{0}}{2} \mathrm{e} \delta=\frac{\delta_{0}}{2}$, sendo $\mu_{0}$ o valor de $\mu$ para $\delta=0$ e $\delta_{0}$ o valor de $\delta$ para $\mu=0$.

HIRSCHMANN (1958) enquadra os ejetores no grupo de bombas com processo dinâmico de trabalho, segundo o método de impulso. $\mathrm{O}$ seu princípio de funcionamento se baseia na transformação de energia e, portanto, qualquer valor de suas características depende da variação de outros valores. Assim, variando-se a altura de elevação, consequentemente, ocorrerão significativas mudanças na vazão.

Nos casos de elevação de água por meio de fontes hidráulicas de energia, pode-se obter o rendimento do conjunto envolvido pela relação entre a potência teórica de elevação $\left(\mathrm{N}_{1}\right)$ e a potência teórica motriz $(\mathrm{N})$, ou seja:

$$
\mathrm{n}=\frac{\mathrm{N}_{1}}{\mathrm{~N}} \text { sendo } \mathrm{N}_{1}=\frac{\mathrm{Q}_{2} \cdot \mathrm{H} \cdot \gamma}{75}(\mathrm{CV}) \text { e } \mathrm{N}=\frac{\mathrm{Q}_{1} \cdot \mathrm{h} \cdot \gamma}{75} \text { (CV) }
$$


teremos $\quad n=\frac{Q_{2} H}{Q_{1} h}$

na qual, $Q_{1}$ é a vazão motriz disponível. Logo, a vazão $Q_{2}$ que se pode elevar será:

$$
\mathrm{Q}_{2}=\mathrm{n} \frac{\mathrm{Q}_{1} \mathrm{~h}}{\mathrm{H}}
$$

Para o caso dos ejetores o rendimento depende não só das alturas de elevação e de queda, mas também da altura de aspiração. Geralmente estas alturas são expressas pelas pressões correspondentes, significando $\mathrm{p}_{\mathrm{e}}$ a pressão da água motriz na entrada do ejetor, $p_{s}$ a pressão imediatamente depois do ejetor e $p_{a}$ a pressão reinante na câmara de aspiração.

Segundo G.FLÜGEL ${ }^{1}$, citado por HIRSCHMANN (1958), qualquer ejetor de água tem como valor característico o quociente $\mu$, dado por

$$
\mu=\frac{\mathrm{P}_{\mathrm{s}^{\prime}}-\mathrm{P}_{\mathrm{a}}}{\mathrm{P}_{\mathrm{e}}-\mathrm{P}_{\mathrm{s}}}
$$

Se $\mathrm{Q}_{1}$ significa a quantidade de água motriz e $\mathrm{Q}_{2}$ a quantidade de água a ser elevada, o respectivo quociente se indica por

$$
\delta=\frac{\mathrm{Q}_{2}}{\mathrm{Q}_{1}}
$$

e, então, o rendimento do ejetor será:

$$
\mathrm{n}=\mu \cdot \delta
$$

O mesmo HIRSCHMANN (1958) propõe métodos simples, analíticos e gráficos, para determinar, com aproximação, sem o auxílio de ensaios de laboratório, a característica altura-vazão de um conjunto bomba-ejetor, partindo das características particulares da bomba e do ejetor.

1 G.FLÜGEL, VDI-ZEITSCHRIFT Bd. 83, Nr.38. 
Segundo PETERS (1959), a construção de ejetores de grande capacidade teve lugar, pela primeira vez, na Austria, com as experiências realizadas inicialmente por STEINWENDER e, mais tarde, por SCHULZ e FASOL. Tais experiências constavam, em essência, de avaliações do desempenho de um sistema constituído por uma fonte em cota elevada, fornecendo água e energia por intermédio de ejetores a uma fonte de nível mais baixo, e a água de ambas encaminhada para um reservatório intermediário que, por sua vez, alimentava uma usina hidroelétrica. Nesses trabalhos, com ejetores de grandes dimensões e Número de REYNOLDS elevado, foi possível alcançar rendimento da ordem de 0,38. 


\section{MATERIAL E MÉTODOS}

Os trabalhos aqui relatados foram conduzidos no Laboratório de Hidráulica do Departamento de Engenhaira Rural da Escola Superior de Agricultura "Luizde Queiroz"/Universidade de São Paulo, situado no Município de Piracicaba, Estado de São Paulo, cujas coordenadas geográficas são: latitude $22^{\circ} 42^{\prime} 30^{\prime \prime} \mathrm{S}$, longitude $47^{\circ} 30^{\prime} 00^{\prime \prime} \mathrm{W}$ e altitude média de $576 \mathrm{~m}$.

\subsection{Material}

\subsubsection{Bombas Centrífugas}

Para o controle das vazões e alturas manométricas requeridas no experimento, foram utilizadas duas bombas centrífugas, disponíveis no Laboratório de Hidráulica, cujas características são apresentadas no Quadro 1.

Quadro 1 - Características das bombas centrífugas

\begin{tabular}{|c|c|c|}
\hline ESPECIFICAÇÃO & MARK BDS9 & KSB-WL $80 / 5$ \\
\hline Potência (C.V.) & 7,5 & 30 \\
\hline Rotação (rpm) & 3.500 & 1.750 \\
\hline Vazão $\left(\mathrm{m}^{3} / \mathrm{h}\right)$ & 36 & 40 \\
\hline Altura Manométrica (m.c.a.) & 36 & 100 \\
\hline
\end{tabular}




\subsubsection{Ejetores}

Ensaiaram-se dois tipos de ejetores de bombas para poços profundos, disponíveis no mercado, cujo funcionamento se baseia na aplicação imediata da equação de Bernoulli.

As Figuras 3 e 4 mostram, em corte, os ejetores utilizados, cujas características são apresentadas no Quadro 1 .

Quadro 1 - Características dos ejetores.

\begin{tabular}{|l|c|c|}
\hline \multicolumn{1}{|c|}{ PARÂMETRO } & EJETOR 1 & EJETOR 2 \\
\hline \hline$D_{1}$ & 32 & 50 \\
\hline$D_{2}$ & 39 & 47 \\
\hline$D_{3}$ & 25,4 & 55 \\
\hline$d_{1}$ & 8 & 12 \\
\hline$d_{2}$ & 13,5 & 44 \\
\hline$L_{1}$ & 48 & - \\
\hline$L_{2}$ & 90 & 177 \\
\hline$N^{0}$ de furos em $A_{1}$ & 1 & 7 \\
\hline$A_{1}$ & 50,27 & 791,7 \\
\hline$A_{2}$ & 143,14 & $1.520,53$ \\
\hline$A_{1} / A_{2}=m$ & 0,35 & 0,52 \\
\hline
\end{tabular}

* $D_{i}, d_{i}$ e $L_{i}$ em mm; $A_{i}$ em $m^{2}$. 


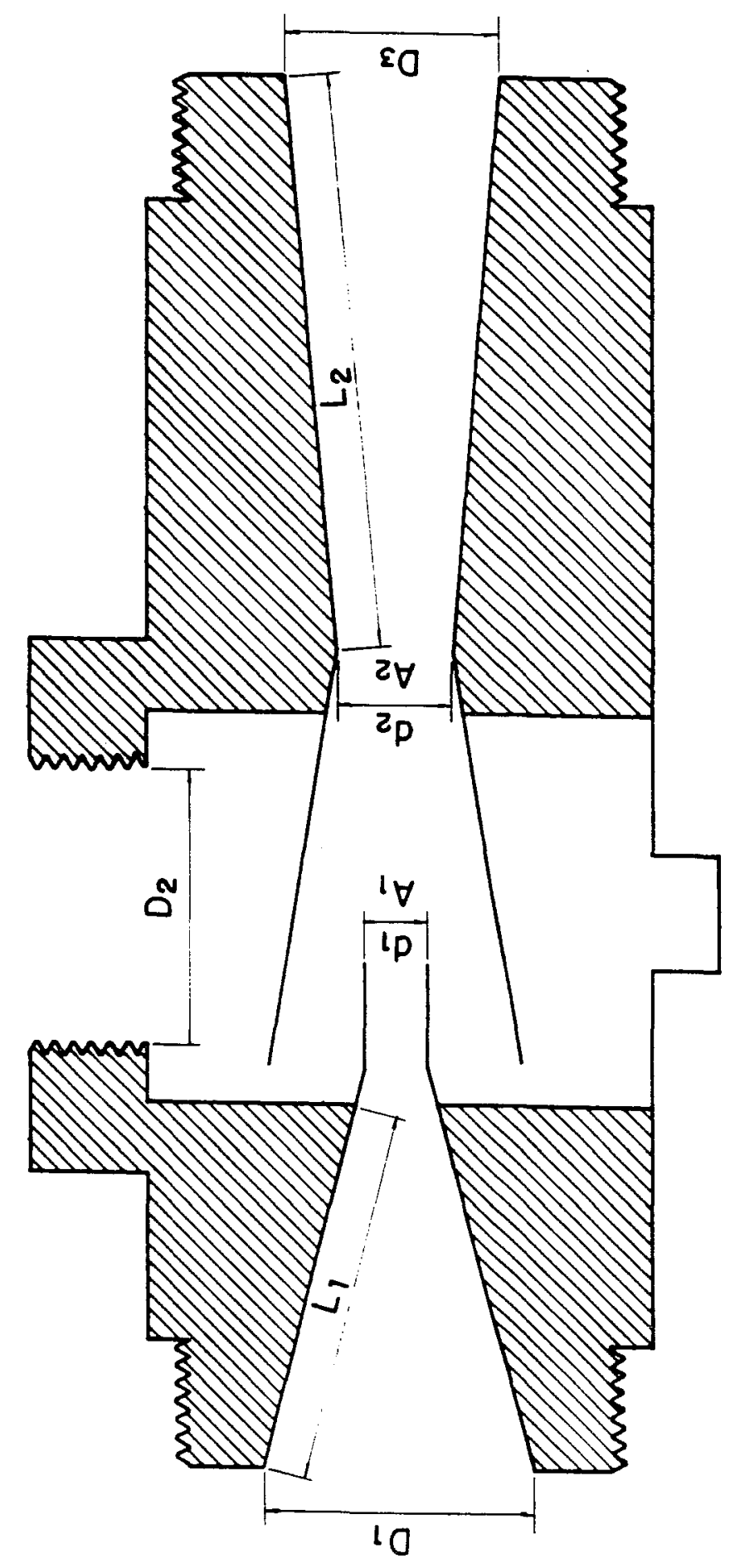

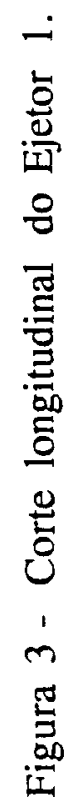




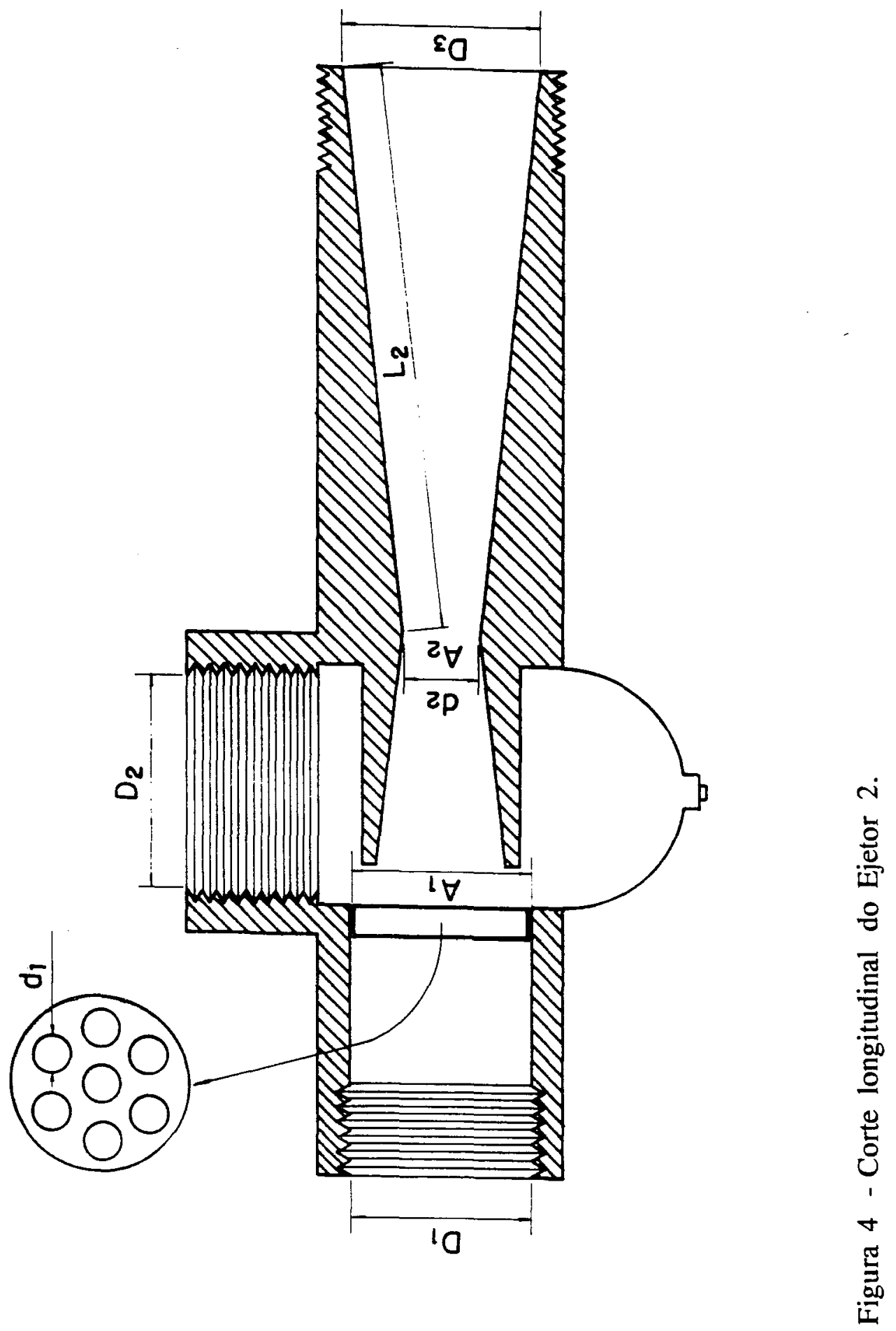




\subsubsection{Medidores de Vazão}

Para a determinação da vazão de água empregaram-se dois medidores A determinação da vazão de ar no Ejetor 1 se obteve com o auxílio de um medidor para gás "LAO" e no Ejetor 2, por meio de um anemômetro instalado no interior de uma tubulação de PVC rígido, com diâmetro de $150 \mathrm{~mm}$ e $3 \mathrm{~m}$ de comprimento.

\subsubsection{Medidor de Vazão Magnético Indutivo (CONAUT)}

É um aparelho que funciona com base na Lei de FARADAY e, no caso, o campo magnético é gerado pela passagem de uma corrente elétrica entre duas bobinas, o condutor é o fluído de medição e tem como comprimento o diâmetro do tubo.

Para avaliação da vazão nos ensaios com os ejetores foram utilizados os seguintes equipamentos:

EJETOR 1 - medidor de vazão CONAUT-463; $Q=8 \mathrm{~m}^{3} / \mathrm{h}$ conversor de sinais CONAUT-474; $\mathrm{K}=404$

EJETOR 2 - medidor de vazão CONAUT-463; $\mathrm{Q}=30 \mathrm{~m}^{3} / \mathrm{h}$ conversor de sinais CONAUT-474; $\mathrm{K}=468$

Esses medidores apresentam precisão de $0,1 \%$, comprovada em ensaios realizados no Laboratório de Hidráulica do Departamento de Engenharia Rural da ESALQ/USP.

Os medidores CONAUT 463 foram instalados entre trechos retos e horizontais de tubos de ferro galvanizado de $1 \mathrm{~m}$ de comprimento e com diâmetros de 1" e 2",para assegurar ao sistema condições de escoamento uniforme.

\subsubsection{Tubo de Venturi}

Trata-se de um aparelho, em essência, formado por um cone convergente e outro divergente interligados, por um corpo cilíndrico. Através da alteração da 
pressão, durante o escoamento do fluído, causada pela redução da seç̧ão desse conjunto, determina-se a vazão em causa.

O "Tubo de Venturi" utilizado encontra-se instalado, permanentemente, no Laboratório de Hidráulica. Apresenta os diâmetros de 6",4" e 6", está ligado a um manômetro diferencial tipo "U" provido com líquido manométrico azul da MERIAM, de densidade relativa igual a 1,75 e tem como equação geral

$$
\mathrm{Q}=3,342429 \mathrm{H}^{1 / 2} \text {. }
$$

onde $Q$ é a vazão em $1 / \mathrm{s}$ e $\mathrm{H}$ é a altura da coluna manométrica $\mathrm{em} \mathrm{cm}$.

\subsubsection{Medidor para gás "LAO"}

Este tipo de medidor foi utilizado na determinação da vazão de ar para o Ejetor 1 e apresenta as seguintes características:

$$
\begin{aligned}
& \text { Vazão máxima }=7 \mathrm{~m}^{3} / \mathrm{h} \\
& \text { Vazão mínima }=0,02 \mathrm{~m}^{3} / \mathrm{h} \\
& \text { Pressão máxima }=1 \mathrm{mca}
\end{aligned}
$$

\subsubsection{Anemômetro}

Os dados de velocidade do ar foram obtidos com o auxílio de um anemômetro portátil CASELLA, com precisão de $+-1 \%$, instalado no interior de uma tubulação de PVC rígido com $150 \mathrm{~mm}$ de diâmetro, e de um cronômetro. A vazão de ar foi determinada por meio da equação da continuidade.

\subsubsection{Medidores de Pressão}

As medidas da pressão de alimentação se realizaram mediante um transdutor de pressão com capacidade para $10 \mathrm{Kgf} / \mathrm{cm}^{2}$, acoplado a um indicador digital microprocessado, com precisão de $0,1 \%$. Para medir a pressão de sucção foi utilizado um vacuômetro coluna de mercúrio, com escala em milímetros. 


\subsection{MÉTODOS}

\subsubsection{Esquemas de montagem dos equipamentos}

Para a realização dos ensaios, o Ejetor 1 foi acoplado a uma bomba centrífuga MARK BDS9 e o Ejetor 2 a uma bomba centrífuga KSB-WL 80/5. Essas adaptações possibilitaram uma avaliação do desempenho dos ejetores, quanto aos volumes de ar ou de água succionados na unidade de tempo, sob pressões de alimentação constantes. As fotografias das Figuras 5,6,7, e 8 e os esquemas das Figuras 9, 10,11 e 12, mostram detalhes acerca da montagem dos equipamentos.

Para a realização dos ensaios com os ejetores foram adotadas as seguintes pressões de alimentação:

Ejetor 1: $10-20-30-40-50-60-70$ m.c.a

Ejetor 2: $10-20-30-40-50$ m.c.a.

O ajuste dessas pressões se conseguiu por meio de válvulas gaveta, de 3" para o Ejetor 1 e de 6" para o Ejetor 2, e um transdutor de pressão com indicador digital e precisão de $0,1 \%$. Para controlar as pressões de sucção, empregou-se uma válvula agulha para o Ejetor 1 , uma válvula gaveta de 2 " para 0 Ejetor 2, e um vacuômetro de coluna de mercúrio.

\subsubsection{Parâmetros de desempenho}

Avaliou-se a razão vazão de sucção e pressão de sucção para cada ejetor, tanto para o caso de sucção de água como para o de sucção de ar, por meio de vinte e quatro ensaios, cada um deles sob condição de pressão de alimentação constante. Resultaram pares de valores, vazão de sucção e pressão de sucção, para cada ejetor, sendo estabelecidas sete diferentes pressões para o Ejetor 1 e cinco para o Ejetor 2, totalizando doze determinações para sucção de água e doze para sucção de ar. 


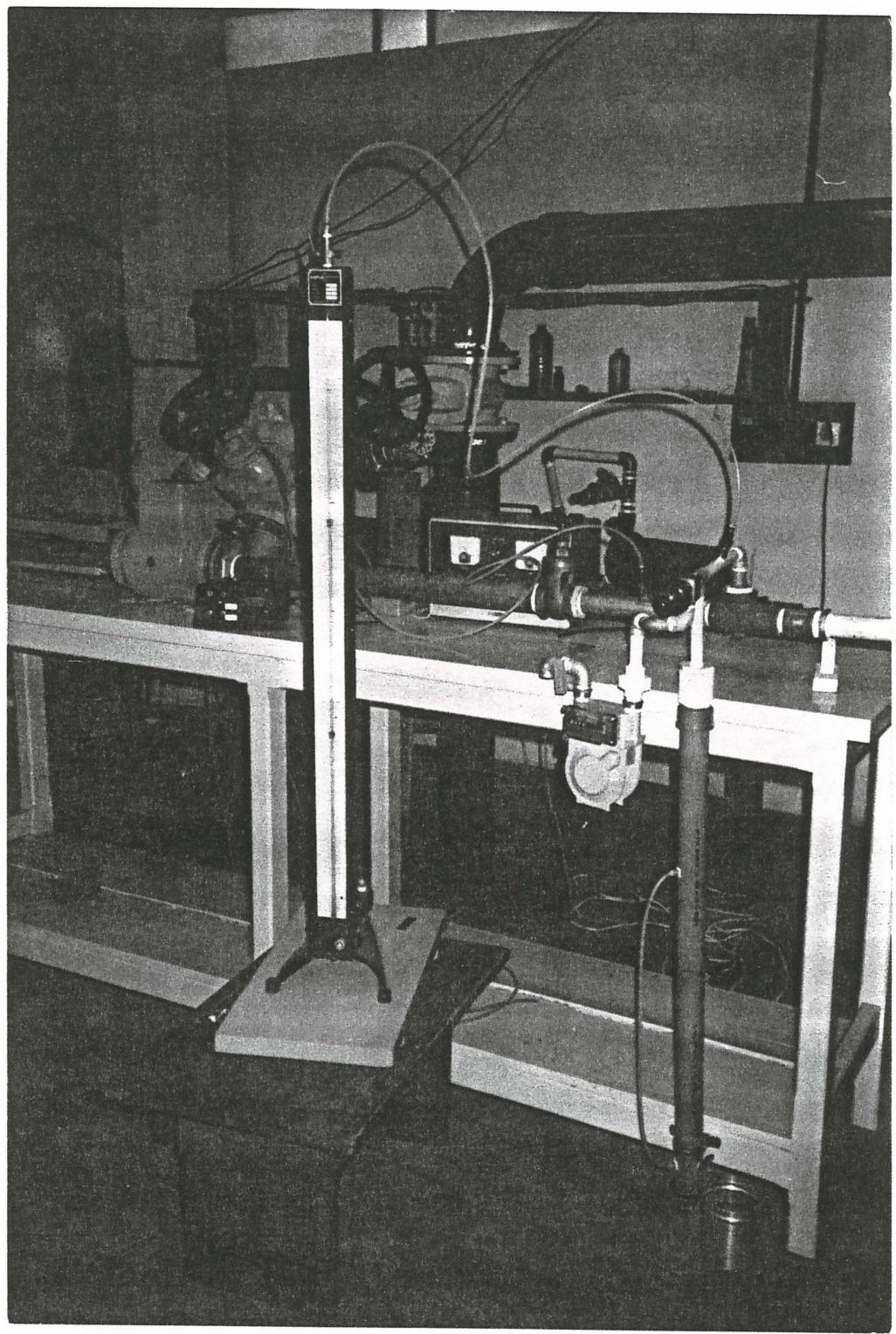

Figura 5 - Montagem para ensaios com o Ejetor 1 succionando ar. 


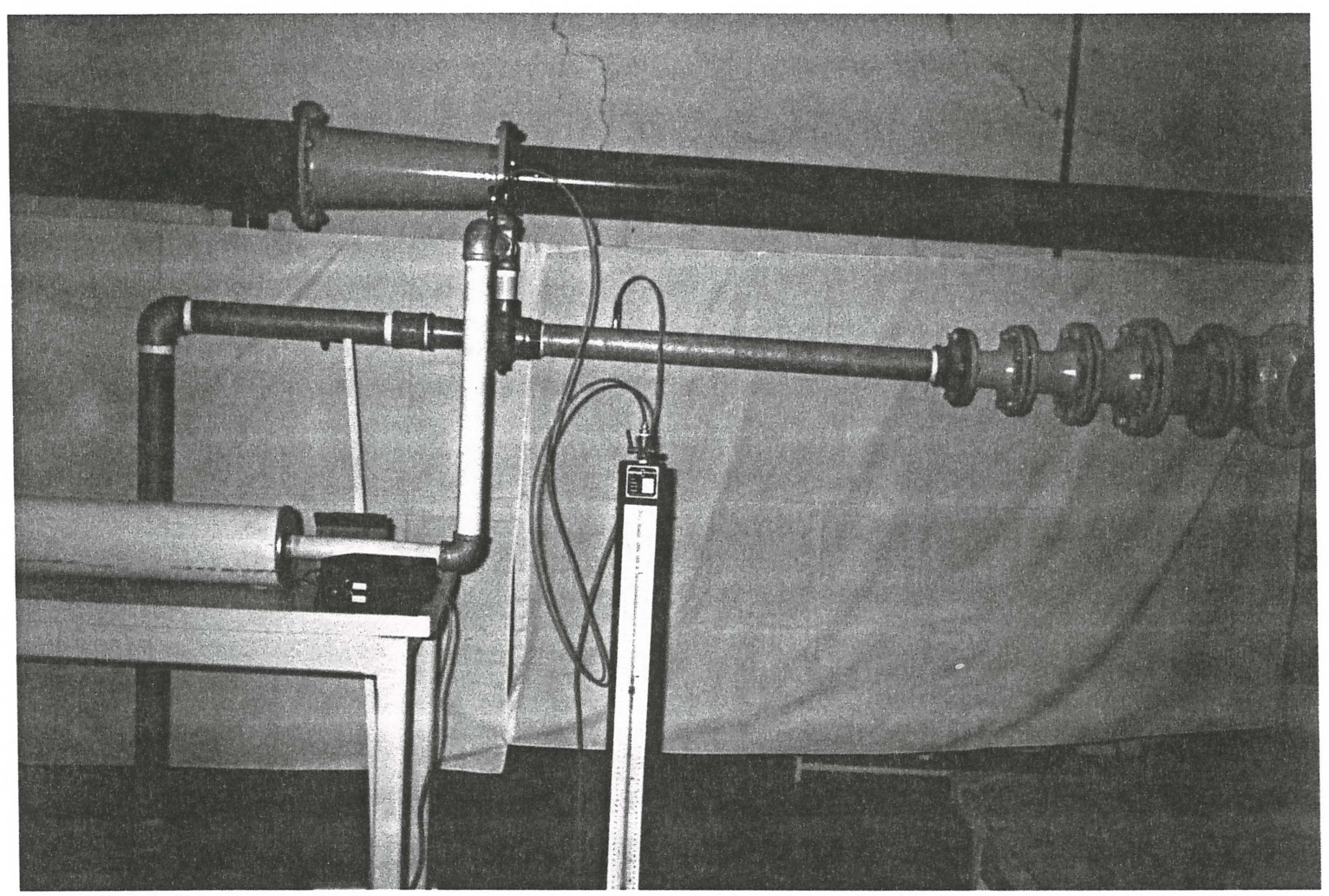

Figura 6 - Montagem para ensaios com o Ejetor 2 succionando ar. 


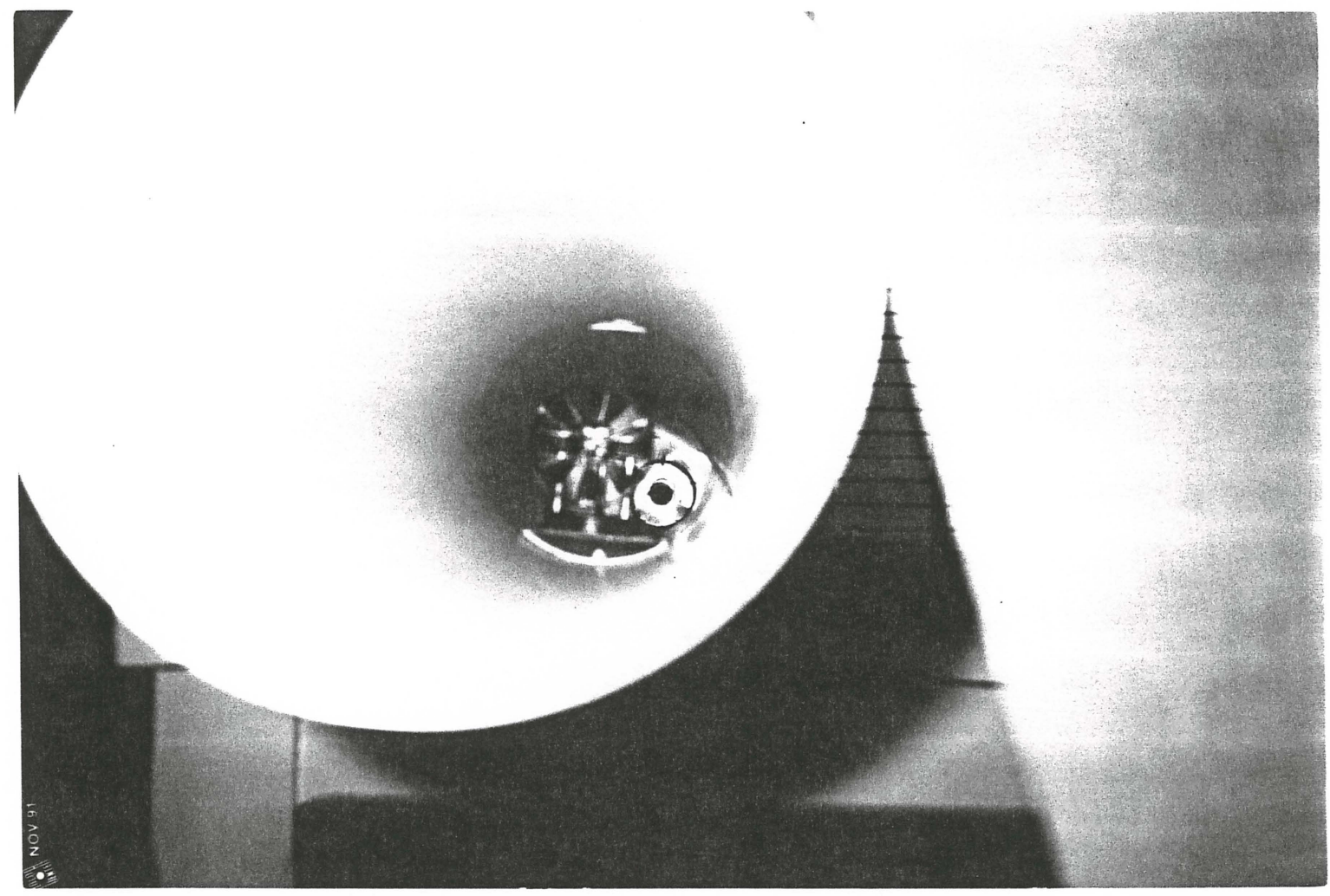

Figura 7 - Tubo de PVC rígido com anemômetro. 


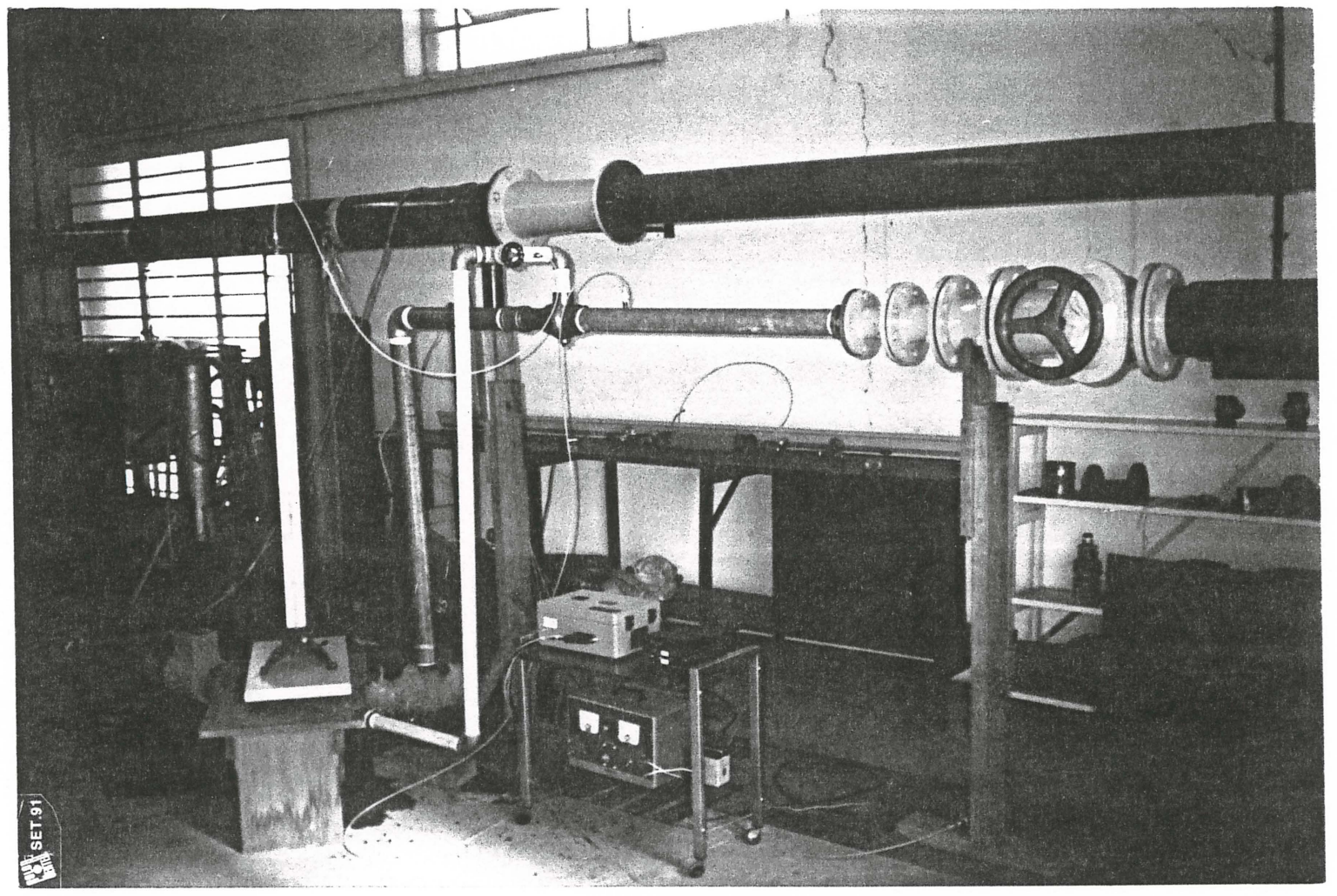

Figura 8 - Montagem para ensiaos com o Ejetor 2 succionando água. 

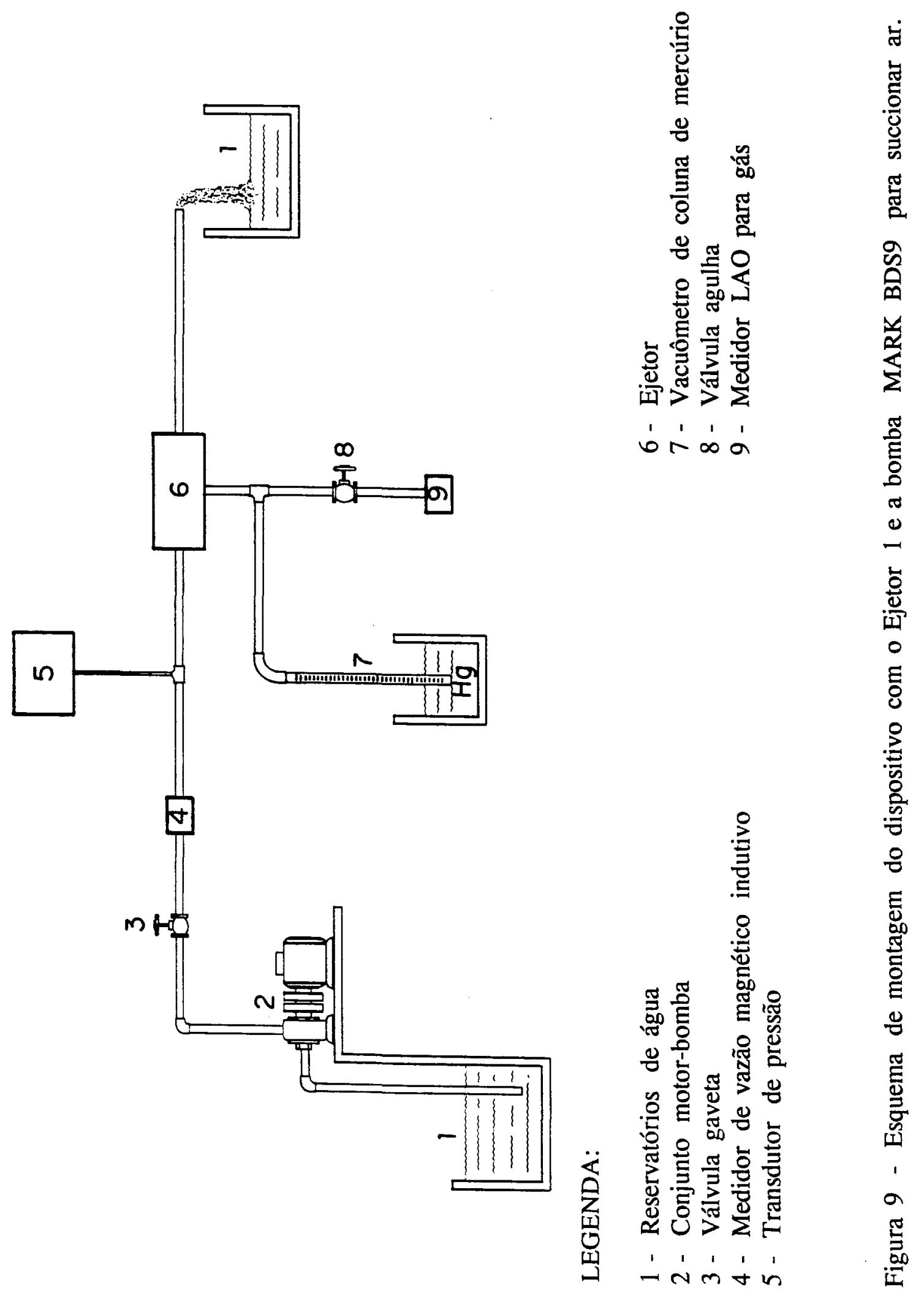

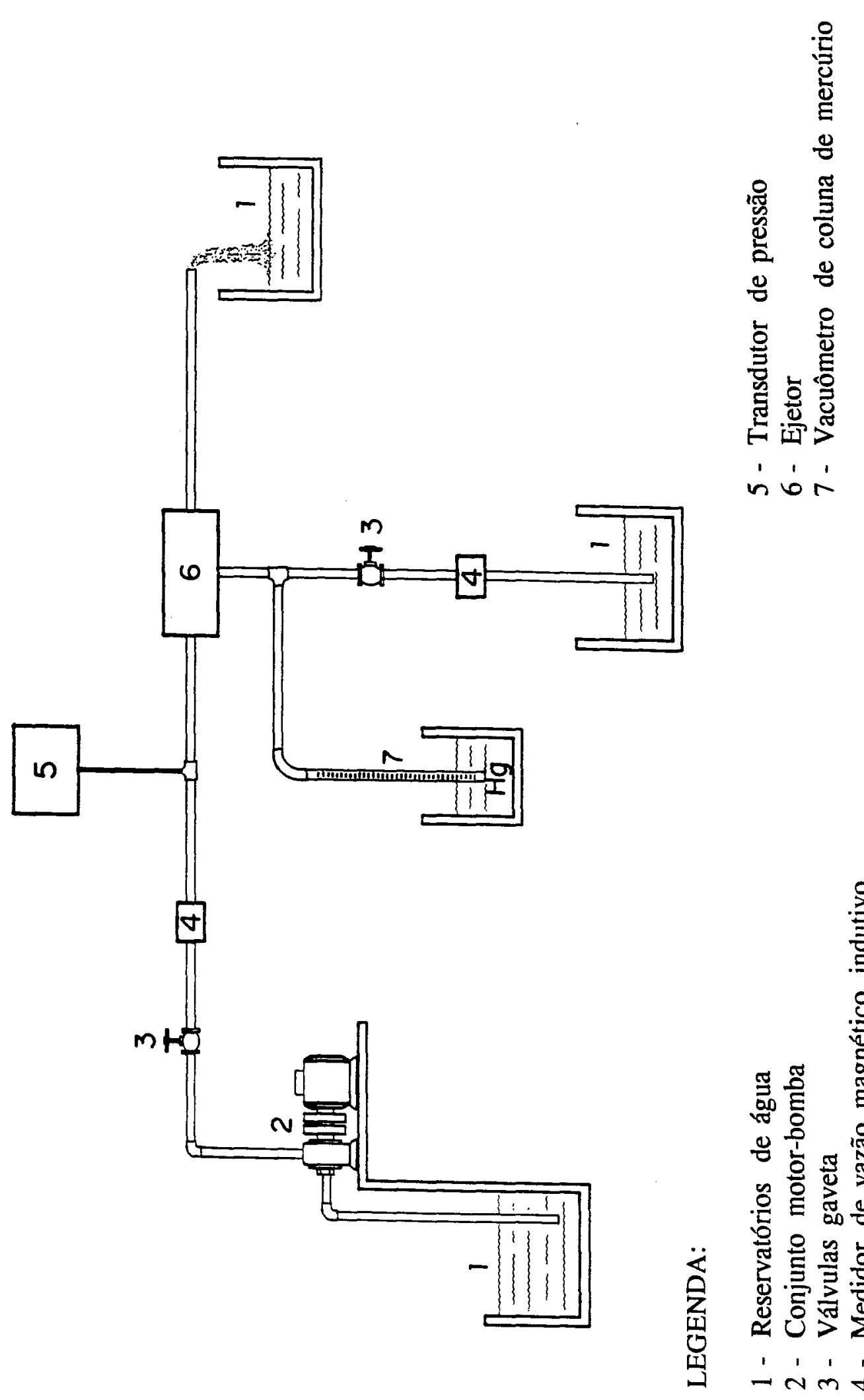

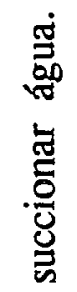

in

芴

คิ

$\sum$

हूँ

$\pi$

0

일

0

ธ్

:

.

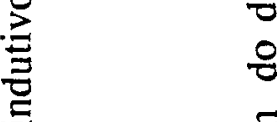

ํㅗํ हี

응

\&

宽

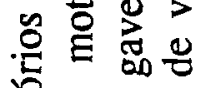

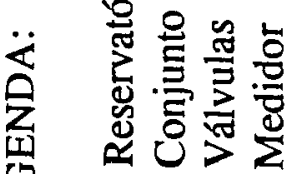

焉穴守

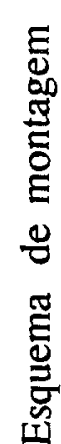

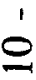

䒿 

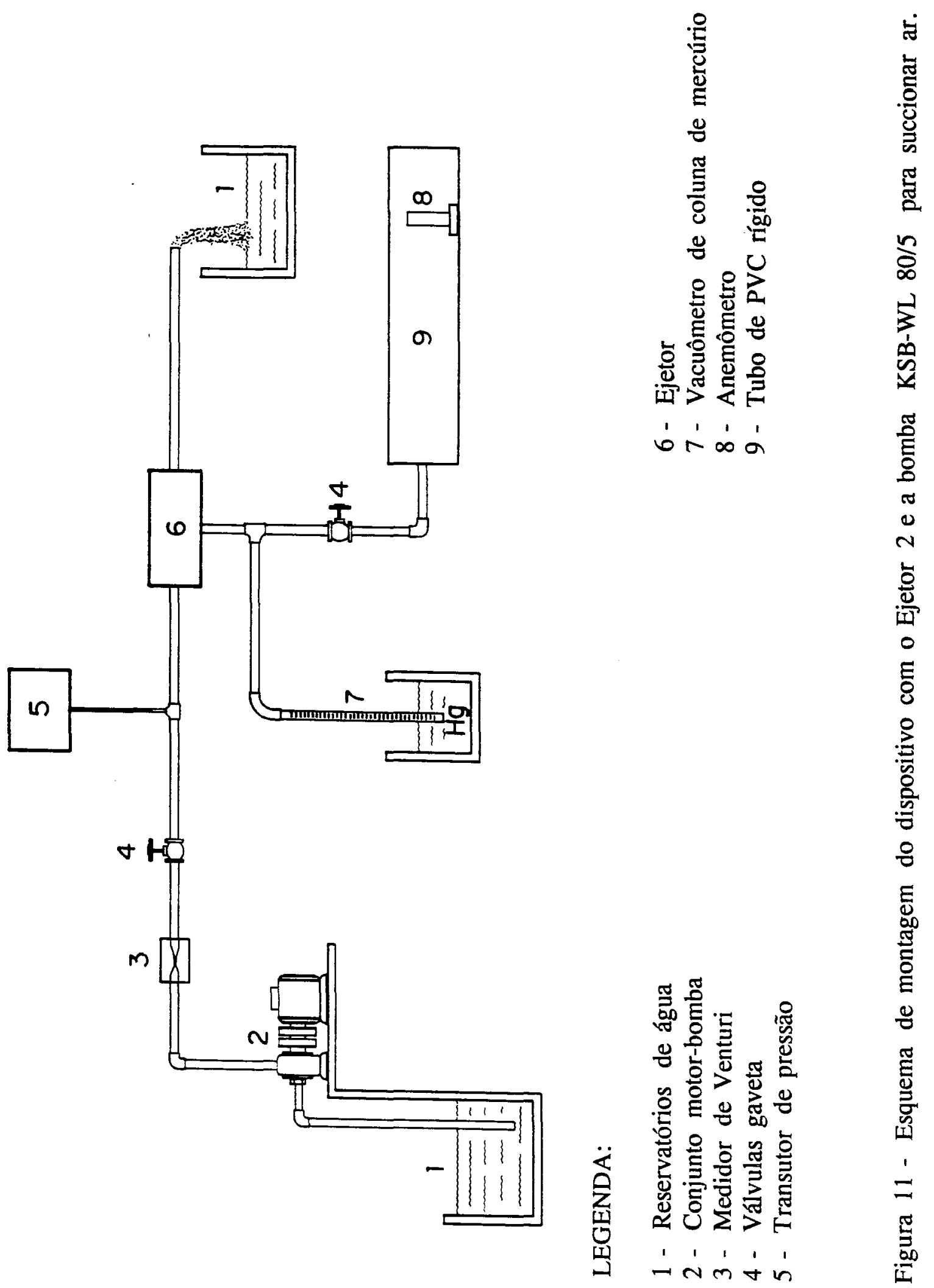


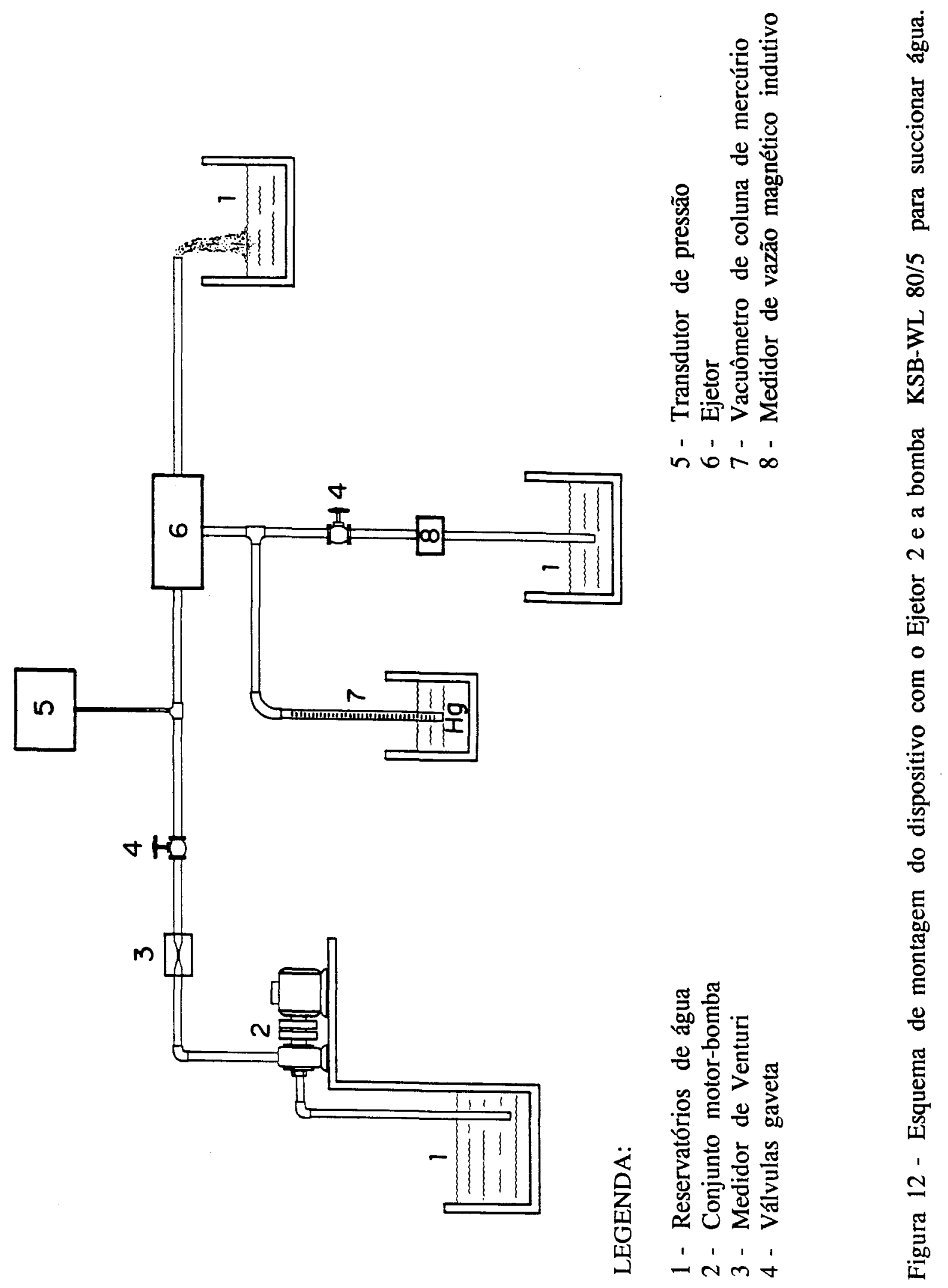




\subsubsection{Curva vazão de sucção versus pressão de sucção}

Com os pares de valores, vazão de sucção e pressão de sucção, correspondentes, foram construídas curvas para demonstrar se havia interdependência entre esses dois parâmetros. Cada curva foi ajustada através da análise de regressão, com a equação do tipo:

$$
\mathrm{q}=\mathrm{K} \mathrm{H}^{\mathrm{x}}
$$

sendo:

$$
\begin{aligned}
& \mathrm{q}=\text { vazão de sucão }\left(\mathrm{m}^{3} / \mathrm{s}\right) ; \\
& \mathrm{H}=\text { pressão absoluta de sucção }(\mathrm{Pa}) ; \\
& \mathrm{K} \text { e } \mathrm{x}=\text { constantes do ejetor }
\end{aligned}
$$

Este mesmo modelo foi utilizado, tanto para sucção de água como para sucção de ar, sendo que para o ar a vazão foi medida à pressão atmosférica e corrigida para a pressão de operação, a partir da equação:

$$
Q_{\text {corrigida }}=\frac{\rho_{\text {atm }} \cdot Q_{\text {suc }}}{\rho_{\text {corrigida }}}
$$

sendo:

$\mathrm{Q}$ corrigida = vazão de sucção de ar à pressão de operação $\mathrm{em} \mathrm{m}^{3} / \mathrm{s}$;

Qsuc $=$ vazão de sucção de ar à pressão atmosférica $\mathrm{em} \mathrm{m}^{3} / \mathrm{s}$;

$\rho$ atm $=$ massa específica do ar à pressão atmosférica $\mathrm{em} \mathrm{Kg} / \mathrm{m}^{3}$;

$\rho$ corrigida $=$ massa específica do ar à pressão de operação em $\mathrm{Kg} / \mathrm{m}^{3}$.

Para a massa específica do ar à pressão atmosférica foi adotado o valor $1,29 \mathrm{Kg} / \mathrm{m}^{3}$. 
Pela teoria dos gases podemos considerar que:

$\mathrm{PV}=\mathrm{NRT}$;

$\mathrm{P}=$ pressão absoluta $(\mathrm{Pa}) ;$

$\mathrm{N}=$ número de moles;

$\mathrm{R}=$ constante universal dos gases $=8,312 \mathrm{~m} \cdot \mathrm{N} / \mathrm{Kg} \cdot \mathrm{mol} . \mathrm{K}$;

$\mathrm{T}=$ temperatura $\mathrm{K}$.

Sendo:

$\mathrm{N}=\frac{\mathrm{m}}{\mathrm{M}}$

$\mathrm{m}=$ massa do ar, $\mathrm{Kg}$;

$\mathrm{M}=$ massa molecular do ar, $\mathrm{Kg} / \mathrm{mol}$,

teremos:

$\mathrm{PV}=\frac{\mathrm{m} \cdot \mathrm{RT}}{\mathrm{M}}$

isolando a massa $\mathrm{m}$, vem

$$
\mathrm{m}=\frac{\mathrm{MPV}}{\mathrm{RT}}
$$


Sendo a massa específica $(\rho)$ igual a massa por unidade de volume, então,

$$
\rho=\frac{\mathrm{m}}{\mathrm{V}}=\frac{\mathrm{PM}}{\mathrm{RT}}
$$

Considerando a massa molecular do ar, à pressão atmosférica, igual a $29.10^{-3} \mathrm{Kg} / \mathrm{mol}$, e a temperatura $\mathrm{T}$ igual a $300 \mathrm{~K}$, tem-se

$$
\rho=1,163 \times 10^{-5} \times \mathrm{P}
$$

Esta expressão permite calcular a massa específica do ar à pressão considerada.

\subsubsection{Rendimento ( $\mathrm{n}$ )}

Procurou-se avaliar o rendimento energético dos ejetores estudados, conforme o seguinte esquema:

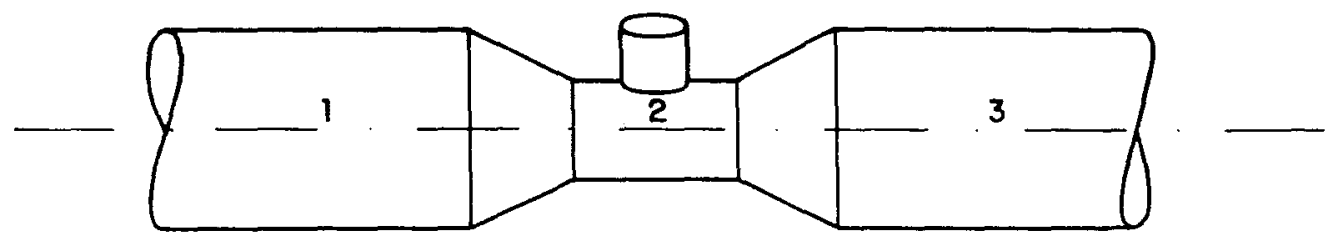

Figura 13 - Corte longitudinal de um Ejetor

em que:

$1=$ ponto de alimentação do ejetor;

2 = ponto de sucção de ar ou água;

$3=$ ponto de descarga de água ou água e ar.

Observando a Figura 13 e pela lei da conservação da energia, tem-se: 


$$
\begin{gathered}
E_{1}+E_{2}=E_{3} \text {, sendo } \\
E_{1}=\text { energia total em 1; } \\
E_{2}=\text { energia total em 2; } \\
E_{3}=\text { energia total em } 3 .
\end{gathered}
$$

Tratando-se de processo isotérmico, as formas de energia envolvidas são a cinética, a piezométrica e a geométrica, sendo que a posição do ejetor, na horizontal, iguala a energia de posição para os três pontos.

Como o objetivo principal reside na avaliação da sucção realizada pelo ejetor, e considerando $E_{2}$ como energia útil (energia para sucção) e $E_{1}$ como energia total de acionamento, o rendimento será:

$$
n=\frac{E_{2}}{E_{1}}
$$

ou ainda

$$
\mathrm{n}=\frac{E c_{2}+E p_{2}}{E c_{1}+E p_{1}}\left(^{*}\right)
$$

em que

$$
\begin{aligned}
& \mathrm{Ec}=\text { energia cinética }=1 / 2 \mathrm{~m} \mathrm{~V}^{2} \\
& \mathrm{Ep}=\text { energia piezométrica }=\mathrm{P} . \theta
\end{aligned}
$$

* Os índices sob as variáveis indicam as posições. 
Considerando a energia por unidade de tempo $(\Delta \mathrm{T})$, tem-se:

$$
\begin{aligned}
& \frac{E c}{\Delta T}=\frac{m V^{2}}{2 \cdot \Delta T} \\
& \frac{E p}{\Delta T}=\frac{P . \theta}{\Delta t}
\end{aligned}
$$

sendo: $\quad \mathrm{m}=$ massa $\mathrm{em} \mathrm{Kg}$;

$$
\begin{aligned}
& \theta=\text { volume em } \mathrm{m}^{3} ; \\
& P=\text { pressão em } \mathrm{N} / \mathrm{m}^{2} .
\end{aligned}
$$

Considerando que $m=\rho . \theta$, obtem-se

$$
\frac{E c}{\Delta T}=\frac{\rho \theta \cdot V^{2}}{2 \Delta T}
$$

$$
\text { Desde que o volume por unidade de tempo } \frac{\theta}{\Delta T} \text { nada mais é do que }
$$

a vazão $(Q)$, segue-se que

$$
\frac{E c}{\Delta T}=\frac{\rho Q V^{2}}{2}
$$

Assim como também,

$$
\frac{E p}{\Delta T}=P . Q
$$


O rendimento será definido a partir da combinação das Equações 11, 18 e 19, como segue:

$$
\mathrm{n}=\frac{\rho_{2} \frac{\mathrm{Q}_{2} \cdot \mathrm{V}_{2}^{2}}{2}+\mathrm{P}_{2} \mathrm{Q}_{2}}{\rho_{1} \frac{\mathrm{Q}_{1} \cdot \mathrm{V}^{2}}{2}+\mathrm{P}_{1} \mathrm{Q}_{1}}
$$

$$
\begin{aligned}
& \text { Sendo } V=\frac{Q}{A} \text { chega-se a } \\
& n=\frac{\rho_{2} \frac{Q^{3}}{2 A^{2}}+P_{2} Q_{2}}{\rho_{1} \frac{Q_{1}^{3}}{2 A^{2}}+P_{1} Q_{1}}
\end{aligned}
$$

que permite o cálculo do rendimento, tanto para o ar como para a água. 


\section{RESULTADOS E DISCUSSÃo}

Em função dos resultados obtidos nos ensaios realizados, conforme a metodologia descrita no capítulo anterior, inseriu-se, a seguir, as informações e características mais evidentes que vieram de encontro ao nosso objetivo.

\subsection{Dos ensaios com o Ejetor 1 succionando ar}

Os resultados estão apresentados nas Tabelas 1 a 7 , que mostram as relações entre a pressão absoluta de sucção, vazão de sucção, vazão de alimentação e rendimento para o Ejetor 1, aspirando ar, quando submetido às respectivas pressões de alimentação de $10,20,30,40,50,60$ e 70 metros de columa de água. A representação gráfica dos resultados contidos nas referidas tabelas está apresentada na Figura 14, que mostra a relação entre a vazão de ar succionado e a pressão absoluta de sucção, para as pressões de alimentação ensaiadas (10 a 70 m.c.a).

Na Tabela 8 são mostrados os resultados obtidos com os pares de valores da vazão de ar succionado versus pressão absoluta de sucção, ajustados pela Equação 1 com auxílio da análise de regressão. 
Tabela 1 - Pressão absoluta de sucção, vazão de sucção, vazão de alimentação e rendimento para o Ejetor 1 , succionando ar, à pressão de alimentação de 10 m.c.a.

\begin{tabular}{|c|c||c||c||}
\hline \multicolumn{2}{|c|}{ SUCÇÃO } & ALIMENTAÇÃO & RENDIMENTO \\
\hline $\begin{array}{c}\text { PRESSÃO } \\
\text { ABSOLUTA (m.c.a) }\end{array}$ & VAZÃO (1/h) & VAZÃO(1/h) & $\%$ \\
\hline \hline 0,62 & 0 & 3.465 & 0.00 \\
\hline 1,42 & 64 & 3.420 & 0.95 \\
\hline 2,10 & 121 & 3.375 & 1.81 \\
\hline 2,74 & 171 & 3.330 & 2.60 \\
\hline 3,49 & 231 & 3.262 & 3.58 \\
\hline 4,14 & 276 & 3.252 & 4.29 \\
\hline 4,86 & 351 & 3.127 & 5.68 \\
\hline 5,39 & 416 & 3.112 & 6.77 \\
\hline 6,17 & 470 & 3.022 & 7.87 \\
\hline 6,85 & 67 & 2.977 & 11.55 \\
\hline 7,54 & 1.010 & 2.910 & 17.57 \\
\hline
\end{tabular}

Tabela 2 - Pressão absoluta de sucção, vazão de sucção, vazão de alimentação e rendimento para o Ejetor 1, succionando ar, à pressão de alimentação de 20 m.c.a.

\begin{tabular}{|c|c||c||c||}
\hline \multicolumn{2}{|c|}{ SUCČ̃̃O } & ALIMENTAÇÃO & RENDIMENTO \\
\hline $\begin{array}{c}\text { PRESSÃO } \\
\text { ABSOLUTA (m.c.a.) }\end{array}$ & VAZÃO (1/h) & VAZÃO(l/h) & $\%$ \\
\hline 0,40 & 0 & 4.260 & 0.00 \\
\hline 1,01 & 98 & 4.215 & 0.78 \\
\hline 1,64 & 219 & 4.185 & 1.75 \\
\hline 2,33 & 322 & 4.155 & 2.60 \\
\hline 3,03 & 465 & 4.110 & 3.79 \\
\hline 3,69 & 623 & 4.057 & 5.15 \\
\hline 4,44 & 794 & 4.012 & 6.64 \\
\hline 5,08 & 990 & 3.952 & 8.40 \\
\hline 5,80 & 1.267 & 3.907 & 10.87 \\
\hline 6,59 & 1.437 & 3.877 & 12.43 \\
\hline 7,13 & 1.813 & 3.847 & 15.81 \\
\hline 7,87 & 2.300 & 3.772 & 20.45 \\
\hline
\end{tabular}


Tabela 3 - Pressão absoluta de sucção, vazão de sucção, vazão de alimentação e rendimento para o Ejetor 1 , succionando ar, à pressão de alimentação de 30 m.c.a.

\begin{tabular}{|c|c|c|c|}
\hline \multicolumn{2}{|c|}{ SUCÇÃO } & ALIMENTAÇÃO & RENDIMENTO \\
\hline $\begin{array}{c}\text { PRESSÃo } \\
\text { ABSOLUTA (m.c.a) }\end{array}$ & VAZÃO $(l / h)$ & VAZÃO(l/h) & $\%$ \\
\hline 0,48 & 0 & 4.845 & 0.00 \\
\hline 1,19 & 166 & 4.807 & 0.87 \\
\hline 1,86 & 342 & 4.770 & 1.80 \\
\hline 2,51 & 544 & 4.747 & 2.87 \\
\hline 4,06 & 954 & 4.657 & 5.14 \\
\hline 4,54 & 1.143 & 4.620 & 6.20 \\
\hline 5,20 & 1.489 & 4.597 & 8.12 \\
\hline 5,91 & 2.045 & 4.537 & 11.30 \\
\hline 6,58 & 2.905 & 4.522 & 16.11 \\
\hline
\end{tabular}

Tabela 4 - Pressão absoluta de sucção, vazão de sucção, vazão de alimentação e rendimento para o Ejetor 1 , succionando ar, à pressão de alimentação de 40 m.c.a.

\begin{tabular}{|c|c|c|c|}
\hline \multicolumn{2}{|c|}{ SUCÇÃO } & ALIMENTAÇÃO & RENDIMENTO \\
\hline $\begin{array}{c}\text { PRESSÃO } \\
\text { ABSOLUTA (m.c.a) }\end{array}$ & VAZÃO $(1 / h)$ & VAZÃO(l/h) & $\%$ \\
\hline 0,46 & 0 & 5.422 & 0.00 \\
\hline 1,15 & 192 & 5.377 & 0.71 \\
\hline 1,87 & 413 & 5.362 & 1.54 \\
\hline 2,50 & 633 & 5.347 & 2.37 \\
\hline 3,18 & 948 & 5.295 & 3.58 \\
\hline 3,84 & 1.191 & 5.257 & 4.54 \\
\hline 4,51 & 1.633 & 5.227 & 6.26 \\
\hline 5,24 & 2.360 & 5.197 & 9.09 \\
\hline 6,01 & 3.139 & 5.182 & 12.13 \\
\hline
\end{tabular}


Tabela 5 - Pressão absoluta de sucção, vazão de sucção, vazão de alimentação e rendimento para o Ejetor 1 , succionando ar, à pressão de alimentação de 50 m.c.a.

\begin{tabular}{||c|c||c|c||}
\hline \multicolumn{2}{|c|}{ SUCÇ̃̃o } & ALIMENTACAO & RENDIMENTO \\
\hline $\begin{array}{c}\text { PRESSÃO } \\
\text { ABSOLUTA (m.c.a) }\end{array}$ & VAZÃO (1/h) & VAZAO(l/h) & $\%$ \\
\hline \hline 0,43 & 0 & 0 & 0.00 \\
\hline 1,19 & 224 & 224 & 0.62 \\
\hline 1,86 & 570 & 570 & 1.59 \\
\hline 3,20 & 1.115 & 1.115 & 3.15 \\
\hline 3,91 & 1.627 & 1.627 & 4.63 \\
\hline 4,58 & 2.483 & 2.483 & 7.10 \\
\hline
\end{tabular}

Tabela 6 - Pressão absoluta de sucção, vazão de sucção, vazão de alimentação e rendimento para o Ejetor 1, succionando ar, à pressão de alimentação de 60 m.c.a.

\begin{tabular}{||c|c||c||c||}
\hline \multicolumn{2}{|c||}{ SUCČÃO } & ALIMENTAÇÃO & RENDIMENTO \\
\hline $\begin{array}{c}\text { PRESSÃO } \\
\text { ABSOLUTA (m.c.a) }\end{array}$ & VAZÃO (l/h) & VAZÃO(l/h) & $\%$ \\
\hline \hline 0,40 & 0 & 6.487 & 0.00 \\
\hline 1,03 & 237 & 6.465 & 0.52 \\
\hline 1,78 & 632 & 6.435 & 1.40 \\
\hline 2,37 & 1.111 & 6.397 & 2.48 \\
\hline 3,07 & 1.876 & 6.375 & 4.20 \\
\hline 3,60 & 2.378 & 6.352 & 5.34 \\
\hline
\end{tabular}

Tabela 7 - Pressão absoluta de sucção, vazão de sucção, vazão de alimentação e rendimento para o Ejetor 1, succionando ar, à pressão de alimentação de 70 m.c.a.

\begin{tabular}{||c|c||c||c|}
\hline \multicolumn{2}{|c|}{ SUCÇÃO } & ALIMENTAÇÃO & RENDIMENTO \\
\hline $\begin{array}{c}\text { PRESSÃO } \\
\text { ABSOLUTA (m.c.a) }\end{array}$ & VAZÃO (l/h) & VAZÃO(l/h) & $\%$ \\
\hline 0,40 & 0 & 6.930 & 0.00 \\
\hline 1,04 & 383 & 6.907 & 0.69 \\
\hline 1,67 & 967 & 6.877 & 1.75 \\
\hline 2,39 & 1.698 & 6.847 & 3.09 \\
\hline
\end{tabular}




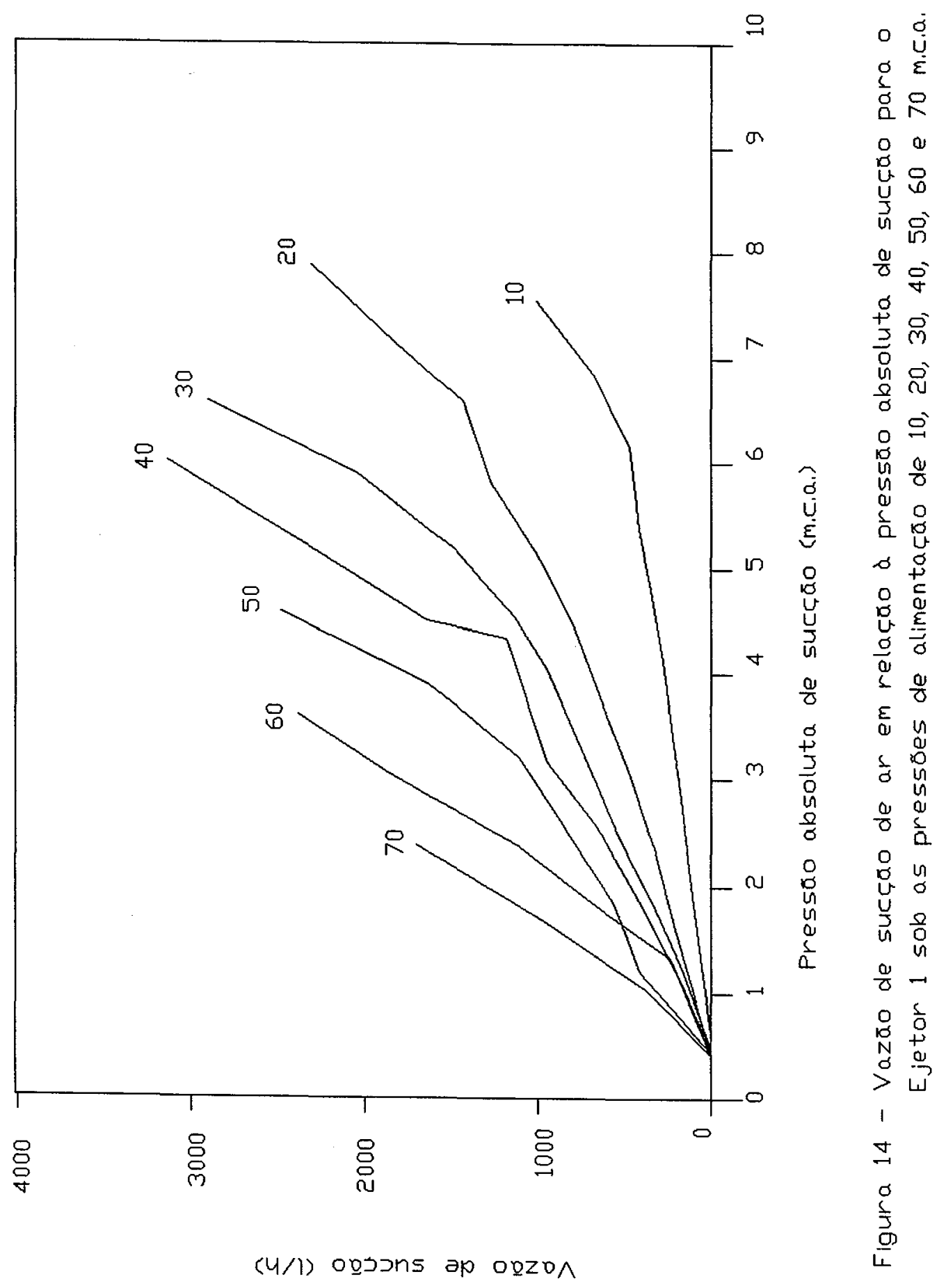


Tabela 8 - Valores dos parâmetros de ajuste da vazão de ar succionado versus pressão absoluta de sucção para o Ejetor 1.

\begin{tabular}{|c|c|c|c|}
\hline $\begin{array}{c}\text { PRESSÃO DE } \\
\text { ALIMENTAÇÃO (m.c.a.) }\end{array}$ & $\mathrm{K}$ & $\mathrm{X}$ & $\mathrm{R}^{2}$ \\
\hline 10 & 2.637 & 0.532 & 0.824 \\
\hline 20 & 12.410 & 0.472 & 0.948 \\
\hline 30 & 7.379 & 0.557 & 0.890 \\
\hline 40 & 3.527 & 0.654 & 0.960 \\
\hline 50 & 3.679 & 0.674 & 0.903 \\
\hline 60 & 0.751 & 0.869 & 0.996 \\
\hline 70 & 2.370 & 0.798 & 0.982 \\
\hline
\end{tabular}

O exame da Figura 14 nos mostra que maiores volumes de água succionada ocorreram para as pressões de alimentação de 40 e 30 m.c.a., com vantagem para a primeira que ainda exigiu menor pressão absoluta de sucção, ou seja, propriamente, 5,85 m.c.a..Verifica-se, ainda, que as menores vazões de sucção ocorrerão para as pressões de alimentação de 10 e 70 m.c.a..

Para as pressões de alimentação ensaiadas observou-se um aumento na vazão de sucção, a medida em que se eleva a pressão absoluta de sucção, naturalmente observados os limites encontrados nos experimentos.

Durante a condução dos ensaios verificou-se que, para a pressão de sucção de ar, havia um valor limite, acima do qual o ejetor deixava de funcionar. Depreende-se que este limite depende da pressão de alimentação e é correspondente aos valores finais apresentados nas Tabelas 1 a 7 .

A partir dos valores dos rendimentos apresentados nas Tabelas 1 a 7 , calculados com a Equação 21, foram construídas as curvas da Figura 15.

Analisando essa figura, pode-se observar que o rendimento do Ejetor 1 aumenta a medida em que se eleva a pressão absoluta de sucção, para as pressões 
de alimentação ensaiadas. As curvas representativas do rendimento em função da pressão absoluta de sucção, para as pressões de alimentação de $20,30,40,50,60$ e 70 m.c.a., praticamente são muito próximas, umas às outras, em toda sua extensão.

Ainda, numa análise global dessas tabelas e figuras, é possível observarse que quanto maior a pressão de alimentação, menor é o campo de atuação do Ejetor $1 \mathrm{e}$ também, menor é o seu rendimento. $\mathrm{O}$ rendimento máximo, equivalente a $20,45 \%$, foi obtido com a pressão de alimentação de 20 m.c.a..

\subsection{Dos ensaios com o Ejetor 1 succionando água}

Os resultados desses ensaios estão apresentados nas Tabelas 9 a 15, que indicam as relações entre a pressão absoluta de sucção, vazão de sucção, vazão de alimentação e rendimento para o Ejetor 1, succionando água, quando submetido às respectivas pressões de alimentação de 10, 20, 30, 40, 50, 60 e 70 m.c.a..

Na Tabela 16 são apresentados os resultados obtidos com os pares de valores da vazão de água succionada versus pressão absoluta de sucção, ajustados pela Equação 1, com auxílio da análise de regressão. 


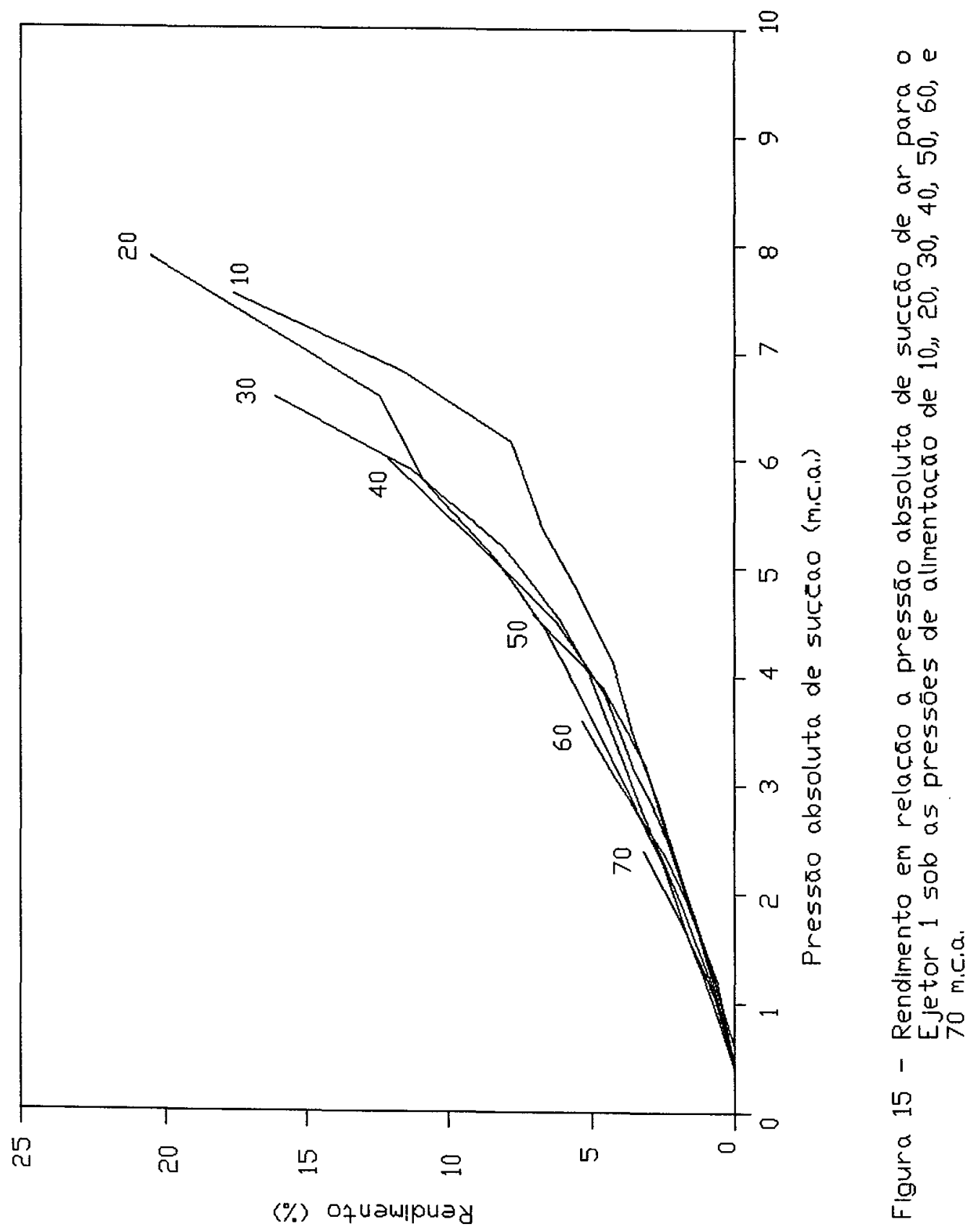


Tabela 9 - Pressão absoluta de sucção, vazão de sucção, vazão de alimentação e rendimento para o Ejetor 1 , succionando água, à pressão de alimentação de 10 m.c.a.

\begin{tabular}{|c|c|c|c|}
\hline \multicolumn{2}{|c|}{ SUCÇÃO } & ALIMENTAÇÃO & RENDIMENTO \\
\hline $\begin{array}{c}\text { PRESSÃO } \\
\text { ABSOLUTA (m.c.a) }\end{array}$ & VAZÃO $(1 / h)$ & VAZÃO(l/h) & $\%$ \\
\hline 0,39 & 0 & 3.465 & 0.00 \\
\hline 1,00 & 292 & 3.188 & 0.46 \\
\hline 1,70 & 412 & 3.110 & 1.14 \\
\hline 2,40 & 542 & 2.986 & 2.21 \\
\hline 3,06 & 656 & 2.970 & 3.43 \\
\hline 3,75 & 784 & 2.962 & 5.04 \\
\hline 4,44 & 940 & 2.936 & 7.22 \\
\hline 4,96 & 1.104 & 2.915 & 9.54 \\
\hline 5,08 & 1.134 & 2.830 & 10.34 \\
\hline
\end{tabular}

Tabela 10 - Pressão absoluta de sucção, vazão de sucção, vazão de alimentação e rendimento para o Ejetor 1 , succionando água, à pressão de alimentação de 20 m.c.a.

\begin{tabular}{|c|c|c|c|}
\hline \multicolumn{2}{|c|}{ SUCÇÃO } & ALIMENTAÇÃO & RENDIMENTO \\
\hline $\begin{array}{c}\text { PRESSÃo } \\
\text { ABSOLUTA (m.c.a) }\end{array}$ & VAZÃO (1/h) & VAZÄO $(l / h)$ & $\%$ \\
\hline 0,39 & 0 & 4.275 & 0.00 \\
\hline 1,02 & 606 & 4.048 & 0.51 \\
\hline 1,66 & 800 & 4.020 & 1.11 \\
\hline 2,39 & 948 & 3.974 & 1.92 \\
\hline 3,04 & 1.060 & 3.999 & 2.71 \\
\hline 3,71 & 1.164 & 3.932 & 3.70 \\
\hline 4,39 & 1.258 & 3.920 & 4.74 \\
\hline 4,77 & 1.306 & 3.896 & 5.38 \\
\hline
\end{tabular}


Tabela 11 - Pressão absoluta de sucção, vazão de sucção, vazão de alimentação e rendimento para o Ejetor 1, succionando água, à pressão de alimentação de 30 m.c.a.

\begin{tabular}{|c|c|c|c|}
\hline \multicolumn{2}{|c|}{ SUCÇÃO } & ALIMENTAÇÃO & RENDIMENTO \\
\hline $\begin{array}{c}\text { PRESSÃO } \\
\text { ABSOLUTA (m.c.a) } \\
\end{array}$ & VAZÃO (l/h) & $\operatorname{VAZÃO}(1 / \mathrm{h})$ & $\%$ \\
\hline 0,36 & 0 & 4.920 & 0.00 \\
\hline 1,03 & 622 & 4.798 & 0.34 \\
\hline 1,66 & 804 & 4.730 & 0.71 \\
\hline 2,32 & 956 & 4.690 & 1.19 \\
\hline 3,04 & 1.084 & 4.676 & 1.77 \\
\hline 3,71 & 1.184 & 4.596 & 2.41 \\
\hline 4,40 & 1.284 & 4.577 & 3.11 \\
\hline 4,70 & 1.322 & 4.558 & 3.43 \\
\hline
\end{tabular}

Tabela 12 - Pressão absoluta de sucção, vazão de sucção, vazão de alimentação e rendimento para o Ejetor 1, succionando água, à pressão de alimentação de 40 m.c.a.

\begin{tabular}{|c|c|c|c|}
\hline \multicolumn{2}{|c|}{ SUCÇÃO } & ALIMENTAÇÃO & RENDIMENTO \\
\hline $\begin{array}{c}\text { PRESSÃO } \\
\text { ABSOLUTA (m.c.a) }\end{array}$ & VAZÃO $(1 / h)$ & VAZÃO(l/h) & $\%$ \\
\hline 0,34 & 0 & 5.497 & 0.00 \\
\hline 1,02 & 616 & 5.408 & 0.29 \\
\hline 1,67 & 816 & 5.390 & 0.64 \\
\hline 2,34 & 966 & 5.360 & 1.06 \\
\hline 3,06 & 1.098 & 5.311 & 1.59 \\
\hline 3,71 & 1.198 & 5.294 & 2.11 \\
\hline 4,42 & 1.300 & 5.280 & 2.74 \\
\hline 4,66 & 1.330 & 5.271 & 2.96 \\
\hline
\end{tabular}


Tabela 13 - Pressão absoluta de sucção, vazão de sucção, vazão de alimentação e rendimento para o Ejetor 1 , succionando água, à pressão de alimentação de 50 m.c.a.

\begin{tabular}{|c|c|c|c|}
\hline \multicolumn{2}{|c|}{ SUCÇÃO } & ALIMENTAÇÃO & RENDIMENTO \\
\hline $\begin{array}{c}\text { PRESSÃO } \\
\text { ABSOLUTA (m.c.a) }\end{array}$ & VAZÄO $(l / h)$ & VAZÃO(l/h) & $\%$ \\
\hline 0,31 & 0 & 6.030 & 0.00 \\
\hline 0,99 & 618 & 5.947 & 0.17 \\
\hline 1,70 & 834 & 5.931 & 0.40 \\
\hline 2,35 & 982 & 5.913 & 0.65 \\
\hline 3,04 & 1.108 & 5.901 & 0.95 \\
\hline 3,75 & 1.222 & 5.872 & 1.31 \\
\hline 4,39 & 1.308 & 5.861 & 1.64 \\
\hline 4,62 & 1.340 & 5.854 & 1.77 \\
\hline
\end{tabular}

Tabela 14 - Pressão absoluta de sucção, vazão de sucção, vazão de alimentação e rendimento para o Ejetor 1, succionando água, à pressão de alimentação de 60 m.c.a.

\begin{tabular}{|c|c|c|c|}
\hline \multicolumn{2}{|c|}{ SUCÇÃO } & ALIMENTAÇÃO & RENDIMENTO \\
\hline $\begin{array}{c}\text { PRESSÃO } \\
\text { ABSOLUTA (m.c.a) }\end{array}$ & VAZÄO (l/h) & VAZÃO(l/h) & $\%$ \\
\hline 0,30 & 0 & 6.510 & 0.00 \\
\hline 1,03 & 632 & 6.465 & 0.14 \\
\hline 1,67 & 830 & 6.434 & 0.31 \\
\hline 2,35 & 986 & 6.421 & 0.52 \\
\hline 3,02 & 1.114 & 6.412 & 0.75 \\
\hline 3,70 & 1.224 & 6.401 & 1.01 \\
\hline 4,39 & 1.318 & 6.393 & 1.30 \\
\hline 4,60 & 1.348 & 6.386 & 1.39 \\
\hline
\end{tabular}


Tabela 15 - Pressão absoluta de sucção, vazão de sucção, vazão de alimentação e rendimento para o Ejetor 1, succionando água, à pressão de alimentação de 70 m.c.a.

\begin{tabular}{||c|c||c||c||}
\hline \multicolumn{2}{|c|}{ SUCÇÃO } & ALIMENTAÇÃO & RENDIMENTO \\
\hline $\begin{array}{c}\text { PRESSÃO } \\
\text { ABSOLUTA (m.c.a) }\end{array}$ & VAZÃO (1/h) & VAZÃO(l/h) & $\%$ \\
\hline \hline 0,28 & 0 & 6.952 & 0.00 \\
\hline 1,02 & 634 & 6.912 & 0.12 \\
\hline 1,68 & 836 & 6.892 & 0.26 \\
\hline 2,34 & 990 & 6.877 & 0.42 \\
\hline 3,04 & 1.126 & 6.871 & 0.62 \\
\hline 3,72 & 1.236 & 6.866 & 0.84 \\
\hline 4,39 & 1.330 & 6.861 & 1.07 \\
\hline 4,54 & 1.356 & 6.857 & 1.12 \\
\hline
\end{tabular}


Tabela 16 - Valores dos parâmetros de ajuste da vazão de água succionada versus pressão absoluta de sucção para o Ejetor 1 .

\begin{tabular}{|c|c|c|c|}
\hline $\begin{array}{c}\text { PRESSÃO DE } \\
\text { ALIMENTAÇÃO (m.c.a.) }\end{array}$ & $\mathrm{K}$ & $\mathrm{X}$ & $\mathrm{R}^{2}$ \\
\hline 10 & 0.157 & 0.813 & 0.983 \\
\hline 20 & 6.687 & 0.491 & 0.998 \\
\hline 30 & 6.671 & 0.493 & 0.998 \\
\hline 40 & 6.192 & 0.501 & 0.998 \\
\hline 50 & 6.490 & 0.498 & 0.998 \\
\hline 60 & 6.298 & 0.501 & 0.998 \\
\hline 70 & 6.177 & 0.504 & 0.998 \\
\hline
\end{tabular}

Com os resultados contidos nas Tabelas 9 a 15 , elaborou-se os gráficos da Figura 16, que permitem verificar-se a variação da vazão de água succionada em relação à pressão absoluta de sucção, para as pressões de alimentação ensaiadas (10 a 70 m.c.a.).

Analisando as curvas da Figura 16, verifica-se que para um aumento na pressão de alimentação de 10 m.c.a. para 20 m.c.a., ocorre uma diferença relevante na relação entre a vazão de água succionada e a pressão absoluta de sucção. Já aumentos progressivos de 20 m.c.a. até 70 m.c.a. não provocaram alterações acentuadas nessa relação.

Os limites de operação do Ejetor 1 succionando água, praticamente não sofreram influência da pressão de alimentação. Também, com as pressões de alimentação de 20 a 70 m.c.a.,pode-se obter, praticamente, a mesma relação vazão de sucção/pressão absoluta de sucção.

Com os resultados dos rendimentos que constam das Tabelas 9 a 15 , calculados com a Equação 21, construíram-se as curvas da Figura 17. Através da mesma verificam-se: a) quanto maior a pressão absoluta de sucção maior é o 


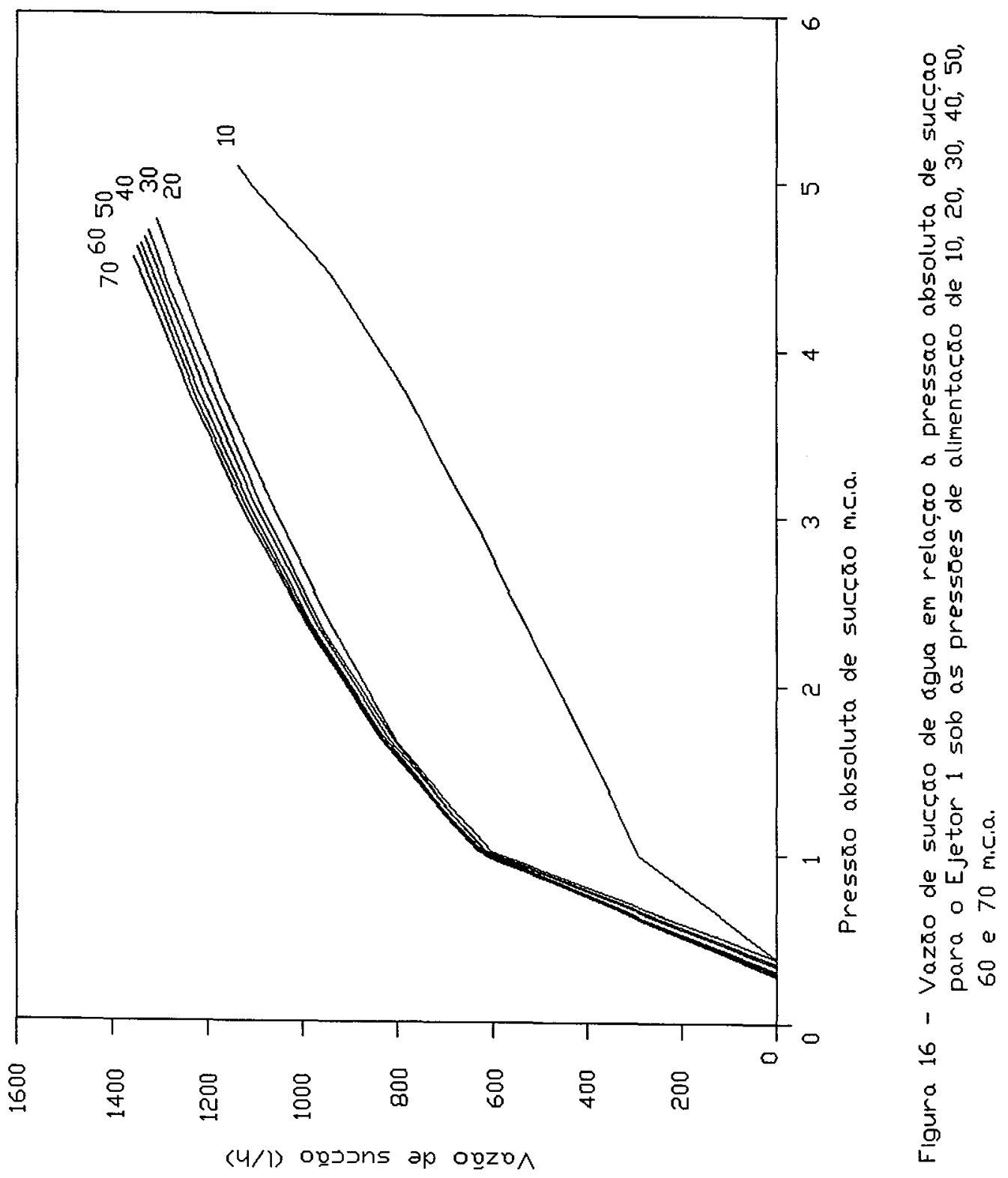


rendimento do ejetor; b) quanto menor a pressão de alimentação maior é o rendimento do ejetor.

Para o Ejetor 1, succionando água, o rendimento máximo, igual 10,34\%, foi obtido para a pressão de alimentação de 10 m.c.a..

Pode-se notar, ainda na Figura 17, que para o Ejetor 1 succionando água, a pressão de alimentação não deve ultrapassar 20 m.c.a.,pois acima deste valor, houve queda no rendimento, além de não ter ocorrido aumento acentuado na relação vazão de sucção versus pressão absoluta de sucção, conforme se pode verificar na Figura 16.

\subsection{Dos ensaios com o Ejetor 2 succionando ar}

Os resultados obtidos se encontram nas Tabelas 17 a 21 , que indicam as relações entre a pressão absoluta de sucção, vazão de sucção, vazão de alimentação e rendimento para o Ejetor 2, succionando ar, quando submetido às respectivas pressões de alimentação de 10, 20, 30, 40 e 50 m.c.a..

Com os resultados inseridos nas Tabelas 17 a 21 construíram-se as curvas da Figura 18, que permitem verificar-se a variação da vazão de ar succionado em relação à pressão absoluta de sucção, para as pressões de alimentação ensaiadas (10 a 50 m.c.a.). 


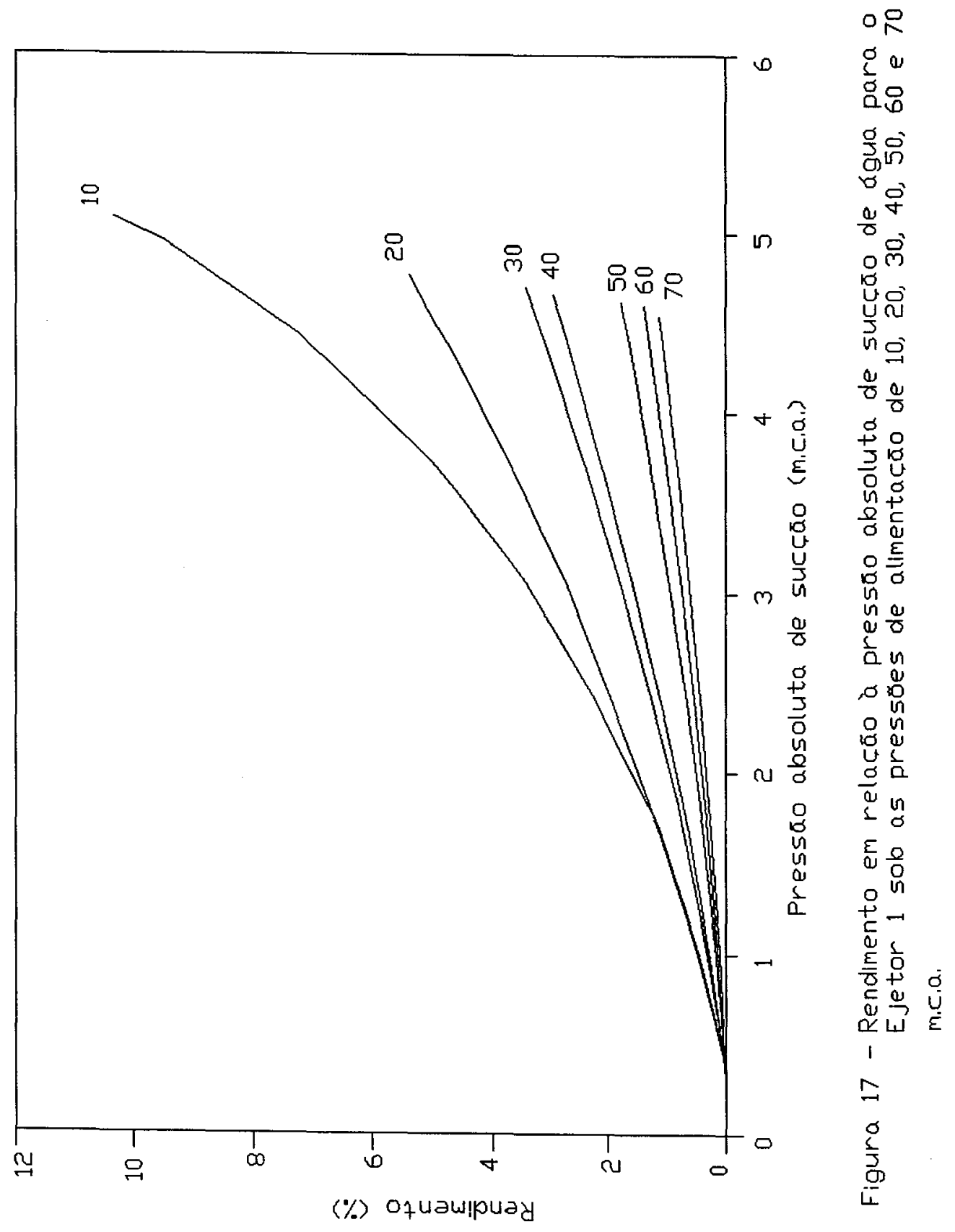


Tabela 17 - Pressão absoluta de sucção, vazão de sucção, vazão de alimentação e rendimento para o Ejetor 2, succionando ar, à pressão de alimentação de 10 m.c.a.

\begin{tabular}{|c|c||c||c|}
\hline \multicolumn{2}{|c||}{ SUCĊ̃̃O } & ALIMENTAÇÃO & RENDIMENTO \\
\hline $\begin{array}{c}\text { PRESSÃO } \\
\text { ABSOLUTA (m.c.a) }\end{array}$ & VAZÃO $(\mathrm{l} / \mathrm{h})$ & VAZÃO(l/h) & $\%$ \\
\hline \hline 0,45 & 0 & 38.131 & 0.00 \\
\hline 6,55 & 5.233 & 34.020 & 7.36 \\
\hline 7,68 & 16.109 & 32.508 & 23.85 \\
\hline 8,40 & 24.125 & 29.952 & 39.09 \\
\hline 9,05 & 37.448 & 27.972 & 65.38 \\
\hline
\end{tabular}

Tabela 18 - Pressão absoluta de sucção, vazão de sucção, vazão de alimentação e rendimento para o Ejetor 2, succionando ar, à pressão de alimentação de 20 m.c.a.

\begin{tabular}{|c|c|c|c|}
\hline \multicolumn{2}{|c|}{ SUCÇÃO } & ALIMENTAÇÃO & RENDIMENTO \\
\hline $\begin{array}{c}\text { PRESSÃo } \\
\text { ABSOLUTA (m.c.a) }\end{array}$ & VAZÃO (l/h) & VAZÃO(l/h) & $\%$ \\
\hline 0,45 & $\mathbf{0}$ & 46.764 & 0.00 \\
\hline 2,34 & 2.191 & 45.648 & 1.51 \\
\hline 3,68 & 5.956 & 45.036 & 4.16 \\
\hline 4,57 & 8.814 & 44.064 & 6.31 \\
\hline 5,33 & 10.459 & 42.876 & 7.72 \\
\hline 6,22 & 15.525 & 42.012 & 11.72 \\
\hline 7,42 & 22.632 & 40.968 & 17.58 \\
\hline 8,47 & 36.348 & 39.528 & 29.39 \\
\hline 9,62 & 64.739 & 38.808 & 53.52 \\
\hline
\end{tabular}


Tabela 19 - Pressão absoluta de sucção, vazão de sucção, vazão de alimentação e rendimento para o Ejetor 2, succionando ar, à pressão de alimentação de 30 m.c.a.

\begin{tabular}{|c|c|c|c|}
\hline \multicolumn{2}{|c|}{ SUCÇÃO } & ALIMENTAÇÃO & RENDIMENTO \\
\hline $\begin{array}{c}\text { PRESSÃO } \\
\text { ABSOLUTA (m.c.a) }\end{array}$ & VAZÃO (l/h) & VAZÃO(l/h) & $\%$ \\
\hline 0,39 & 0 & 53.820 & 0.00 \\
\hline 1,82 & 1.510 & 53.280 & 0.66 \\
\hline 2,69 & 4.975 & 52.848 & 2.21 \\
\hline 3,79 & 12.368 & 52.452 & 5.54 \\
\hline 4,88 & 21.275 & 52.020 & 9.63 \\
\hline 6,14 & 33.189 & 51.624 & 15.17 \\
\hline 6,99 & 42.838 & 51.048 & 19.84 \\
\hline 7,78 & 50.795 & 50.616 & 23.75 \\
\hline 8,50 & 63.238 & 50.184 & 29.89 \\
\hline 9,60 & 87.646 & 49.752 & 41.91 \\
\hline
\end{tabular}

Tabela 20 - Pressão absoluta de sucção, vazão de sucção, vazão de alimentação e rendimento para o Ejetor 2, succionando ar, à pressão de alimentação de 40 m.c.a.

\begin{tabular}{||c|c||c||c||}
\hline \multicolumn{2}{|c|}{ SUCĊ̃̃O } & ALIMENTAÇÃO & RENDIMENTO \\
\hline $\begin{array}{c}\text { PRESSÃO } \\
\text { ABSOLUTA (m.c.a) }\end{array}$ & VAZÃO (l/h) & VAZÃO $(1 / \mathrm{h})$ & $\%$ \\
\hline \hline 0,35 & 0 & 61.596 & 0.00 \\
\hline 0,96 & 1.162 & 60.876 & 0.36 \\
\hline 1,93 & 5.529 & 60.156 & 1.72 \\
\hline 2,50 & 7.271 & 59.688 & 2.28 \\
\hline 3,37 & 12.955 & 58.932 & 4.13 \\
\hline 4,43 & 26.192 & 58.320 & 8.45 \\
\hline 5,60 & 40.619 & 57.456 & 13.35 \\
\hline 6,59 & 55.025 & 57.060 & 18.25 \\
\hline 7,64 & 76.133 & 56.196 & 25.74 \\
\hline 8,62 & 107.109 & 55.548 & 36.83 \\
\hline 9,53 & 133.566 & 54.864 & 46.70 \\
\hline
\end{tabular}


Tabela 21 - Pressão absoluta de sucção, vazão de sucção, vazão de alimentação e rendimento para o Ejetor 2, succionando ar, à pressão de alimentação de 50 m.c.a.

\begin{tabular}{||c|c||c||c||}
\hline \multicolumn{2}{|c|}{ SUCČ̃̃O } & ALIMENTAÇÃO & RENDIMENTO \\
\hline $\begin{array}{c}\text { PRESSÃO } \\
\text { ABSOLUTA (m.c.a) }\end{array}$ & VAZÃO (l/h) & VAZÃO(l/h) & $\%$ \\
\hline \hline 0,32 & 0 & 66.240 & 0.00 \\
\hline 0,98 & 1.710 & 65.700 & 0.41 \\
\hline 1,67 & 3.569 & 65.340 & 0.85 \\
\hline 2,38 & 11.842 & 64.692 & 2.86 \\
\hline 3,15 & 19.929 & 64.224 & 4.86 \\
\hline 4,69 & 35.140 & 63.324 & 8.72 \\
\hline 5,60 & 47.275 & 62.748 & 11.86 \\
\hline 6,40 & 65.788 & 62.280 & 16.69 \\
\hline 7,27 & 77.249 & 61.812 & 19.77 \\
\hline 8,26 & 95.010 & 61.128 & 24.66 \\
\hline 9,49 & 130.638 & 60.768 & 34.27 \\
\hline
\end{tabular}




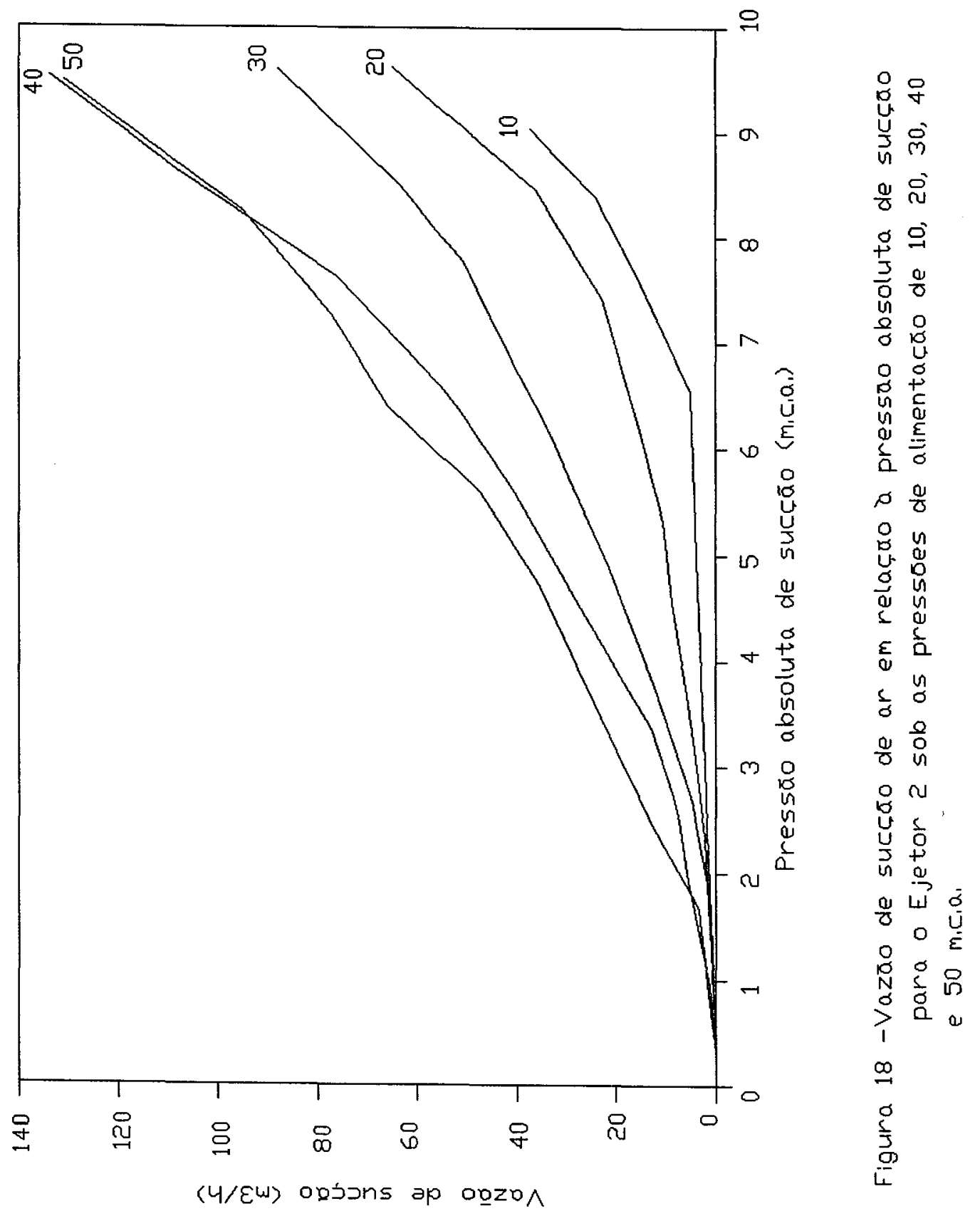


A Tabela 22 mostra os resultados obtidos com os pares de valores da vazão de ar succionado versus pressão absoluta de sucção, ajustados pela Equação 1 , com auxílio da análise de regressão.

Tabela 22 - Valores dos parâmetros de ajuste da vazão de ar succionado versus pressão absoluta de sucção para o Ejetor 2.

\begin{tabular}{|c|r|c|c|}
\hline $\begin{array}{c}\text { PRESSÃO DE } \\
\text { ALIMENTAÇÃO (m.c.a) }\end{array}$ & $\mathrm{K}$ & $\mathrm{X}$ & $\mathrm{R}^{2}$ \\
\hline 10 & 10.933 .18 & 0.196 & 0.988 \\
\hline 20 & 0.030 & 1.251 & 0.926 \\
\hline 30 & 0.019 & 1.344 & 0.976 \\
\hline 40 & 0.877 & 1.039 & 0.987 \\
\hline 50 & 4.002 & 0.917 & 0.944 \\
\hline
\end{tabular}

A análise da Figura 18 mostra um aumento crescente na relação vazão de sucção versus pressão absoluta de sucção, para as pressões de alimentação de 10 m.c.a. a 40 m.c.a.. Comparando-se as curvas relativas às pressões de alimentação de 40 m.c.a. e 50 m.c.a., verifica-se que elas são praticamente coincidentes nas suas extremidades e desiguais para o intervalo de pressão absoluta de sucção de 2 m.c.a a 8 m.c.a.,com os valores de vazão de sucção superiores, em toda a faixa, para a pressão de alimentação de 50 m.c.a.,contudo pode-se adotar, indiferentemente, as pressões de alimentação de 40 m.c.a. ou 50 m.c.a.,para se obter maior vazão de sucção.

Verifica-se ainda, que os limites de operação do Ejetor 2, succionando ar, sob as diferentes pressões de alimentação ensaiadas, ocorrerão, práticamente, a uma mesma pressão absoluta de sucção, de valor próximo à pressão atmosférica. 
Com os resultados dos rendimentos apresentados nas Tabelas 17 a 21 , calculados com a Equação 21, foram constrúidas as curvas da Figura 19.

Nessa figura, que relaciona o rendimento do Ejetor 2 com a pressão absoluta de sucção, é possível observar um decréscimo acentuado do rendimento a medida em que se aumenta a pressão de alimentação. Não foi possível encontrar a razão pela qual houve uma variação crescente do rendimento ocorrida entre as pressões de 30 m.c.a.e 40 m.c.a..

As curvas correspondentes às pressões de alimentação de 30,40 e 50 m.c.a., são, práticamente, coincidentes até a pressão absoluta de sucção de 6,5 m.c.a.,divergindo, após esse valor, até os respectivos limites de operação.

O Ejetor 2, quando succionando ar e sob pressão de alimentação de 10 m.c.a., apresentou o maior rendimento, correspondente a $65,38 \%$.

\subsection{Dos ensaios com o Ejetor 2 succionando água}

Os resultados provenientes desses ensaios estão reunidos nas Tabelas 23, $24,25,26$ e 27 , que mostram as relações entre a pressão absoluta de sucção, vazão de sucção, vazão de alimentação e rendimento, para o Ejetor 2 succionando água, quando submetido às respectivas pressões de alimentação de 10, 20, 30, 40 e 50 metros de coluna de água.

Com os resultados constantes das Tabelas 23 a 27 foram contruídas as curvas da Figura 20, que permitem verificar-se a variação da vazão de água succionada em relação a pressão absoluta de sucção.

Observa-se nessa figura uma descontinuidade na curva da relação vazão de sucção versus pressão de sucção, podendo-se distinguir duas regiões distintas, sendo a primeira, no intervalo de 0,15 a 0,70 m.c.a.de pressão absoluta de sucção, caracterizada por grande sensibilidade da vazão com a pressão, além das curvas apresentarem valores, práticamente coincientes, para todas as pressões de alimentação ensaiadas; a segunda, com curvas coincidentes para as pressões de alimentação de 20 a 50 m.c.a.e pequena sensibilidade da vazão com a pressão, no intervalo de 0,70 a 2,60 m.c.a. de pressão absoluta de sucção. 


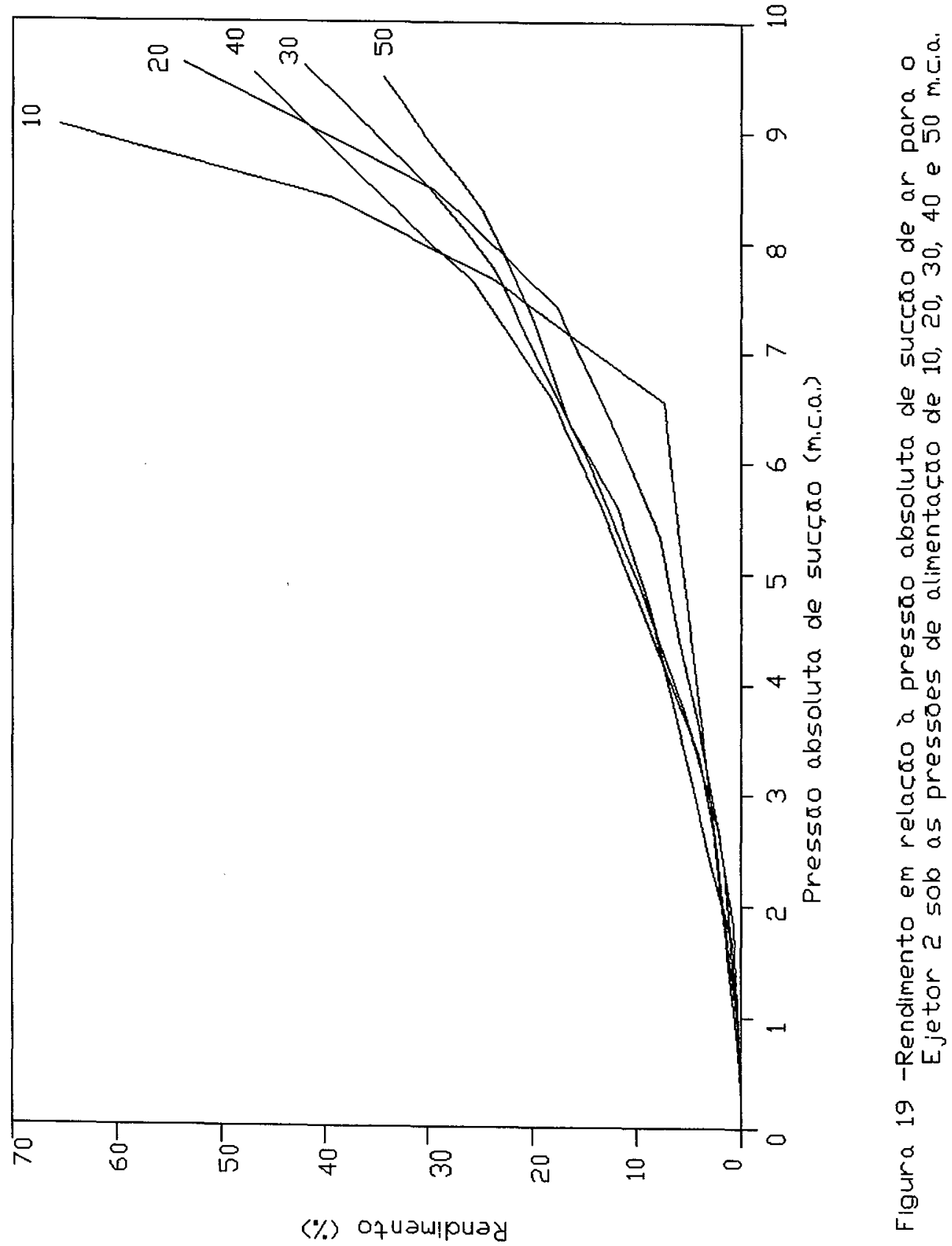


Tabela 23 - Pressão absoluta de sucção, vazão de sucção, vazão de alimentação e rendimento para o Ejetor 2, succionando água, à pressão de alimentação de 10 m.c.a.

\begin{tabular}{|c|c|c|c|}
\hline \multicolumn{2}{|c|}{ SUCÇÃO } & \multirow{2}{*}{$\begin{array}{c}\text { ALIMENTAÇÃO } \\
\text { VAZÃO }(1 / h)\end{array}$} & \multirow{2}{*}{$\begin{array}{c}\text { RENDIMENTO } \\
\%\end{array}$} \\
\hline $\begin{array}{c}\text { PRESSÃO } \\
\text { ABSOLUTA (m.c.a) }\end{array}$ & VAZĀO (l/h) & & \\
\hline 0,24 & 0 & 38.412 & 0.00 \\
\hline 0,39 & 2.100 & 38.210 & 0.01 \\
\hline 0,46 & 4.320 & 37.094 & 0.06 \\
\hline 0,58 & 10.320 & 36.947 & 0.89 \\
\hline 0,73 & 13.020 & 36.853 & 1.79 \\
\hline 1,52 & 13.530 & 36.427 & 2.03 \\
\hline 3,10 & 14.760 & 36.051 & 2.67 \\
\hline 3,59 & 15.690 & 35.876 & 3.23 \\
\hline 4,30 & 16.950 & 35.781 & 4.08 \\
\hline
\end{tabular}

Tabela 24 - Pressão absoluta de sucção, vazão de sucção, vazão de alimentação e rendimento para o Ejetor 2, succionando água, à pressão de alimentação de 20 m.c.a.

\begin{tabular}{|c|c|c|c|}
\hline \multicolumn{2}{|c|}{ SUCÇÃO } & \multirow{2}{*}{$\frac{\text { ALIMENTAÇÃO }}{\text { VAZÃO }(1 / h)}$} & \multirow{2}{*}{$\frac{\text { RENDIMENTO }}{\%}$} \\
\hline $\begin{array}{c}\text { PRESSÃO } \\
\text { ABSOLUTA (m.c.a) } \\
\end{array}$ & VAZÃO $(1 / h)$ & & \\
\hline 0,23 & 0 & 45.648 & 0.00 \\
\hline 0,39 & 2.220 & 45.611 & 0.01 \\
\hline 0,46 & 4.290 & 45.371 & 0.03 \\
\hline 0,57 & 10.320 & 44.993 & 0.50 \\
\hline 0,77 & 14.670 & 44.654 & 1.40 \\
\hline 1,48 & 16.230 & 44.431 & 1.91 \\
\hline 1,83 & 17.340 & 44.211 & 2.34 \\
\hline 2,07 & 18.420 & 43.912 & 2.83 \\
\hline 2,70 & 20.610 & 43.841 & 3.97 \\
\hline
\end{tabular}


Tabela 25 - Pressão absoluta de sucção, vazão de sucção, vazão de alimentação e rendimento para o Ejetor 2, succionando água, à pressão de alimentação de 30 m.c.a.

\begin{tabular}{|c|c||c||c||}
\hline \multicolumn{2}{|c||}{ SUCÇÃO } & ALIMENTAÇÃO & RENDIMENTO \\
\hline $\begin{array}{c}\text { PRESSÃO } \\
\text { ABSOLUTA (m.c.a) }\end{array}$ & VAZÃO (l/h) & VAZÃO(l/h) & $\%$ \\
\hline \hline 0,22 & 0 & 56.196 & 0.00 \\
\hline 0,35 & 2.430 & 55.889 & 0.01 \\
\hline 0,49 & 4.110 & 55.417 & 0.02 \\
\hline 0,61 & 11.430 & 55.081 & 0.40 \\
\hline 0,78 & 15.270 & 54.821 & 0.96 \\
\hline 1,21 & 16.140 & 54.219 & 1.14 \\
\hline 1,64 & 16.800 & 53.611 & 1.30 \\
\hline 2,01 & 18.390 & 53.456 & 1.72 \\
\hline 2,35 & 19.650 & 53.312 & 2.10 \\
\hline 2,68 & 20.670 & 52.913 & 2.47 \\
\hline
\end{tabular}

Tabela 26 - Pressão absoluta de sucção, vazão de sucção, vazão de alimentação e rendimento para o Ejetor 2, succionando água, à pressão de alimentação de 40 m.c.a.

\begin{tabular}{|c|c|c|c|}
\hline \multicolumn{2}{|c|}{ SUCÇÃO } & ALIMENTAÇÃO & RENDIMENTO \\
\hline $\begin{array}{c}\text { PRESSÃO } \\
\text { ABSOLUTA (m.c.a) }\end{array}$ & VAZÃO (l/h) & VAZÃO(l/h) & $\%$ \\
\hline 0,21 & 0 & 62.856 & 0.00 \\
\hline 0,39 & 3.210 & 62.651 & 0.01 \\
\hline 0,51 & 7.770 & 62.321 & 0.08 \\
\hline 0,73 & 14.550 & 61.837 & 0.56 \\
\hline 1,02 & 15.540 & 61.641 & 0.71 \\
\hline 1,57 & 16.470 & 61.271 & 0.86 \\
\hline 1,93 & 18.030 & 60.731 & 1.13 \\
\hline 2,32 & 19.530 & 60.325 & 1.45 \\
\hline 2,65 & 20.730 & 59.912 & 1.75 \\
\hline
\end{tabular}


Tabela 27 - Pressão absoluta de sucção, vazão de sucção, vazão de alimentação e rendimento para o Ejetor 2, succionando água, à pressão de alimentação de 50 m.c.a.

\begin{tabular}{|c|c|c|c|}
\hline \multicolumn{2}{|c|}{ SUCÇÃO } & ALIMENTAÇÃO & RENDIMENTO \\
\hline $\begin{array}{c}\text { PRESSÃO } \\
\text { ABSOLUTA (m.c.a) }\end{array}$ & VAZÃO (l/h) & $\operatorname{VAZÃO}(1 / h)$ & $\%$ \\
\hline 0,13 & $\mathbf{0}$ & 67.104 & 0.00 \\
\hline 0,28 & 2.580 & 66.953 & 0.00 \\
\hline 0,43 & 4.800 & 66.741 & 0.02 \\
\hline 0,55 & 12.690 & 66.327 & 0.30 \\
\hline 1,00 & 16.320 & 65.831 & 0.65 \\
\hline 1,40 & 16.740 & 65.543 & 0.70 \\
\hline 1,98 & 19.200 & 65.212 & 1.07 \\
\hline 2,58 & 21.450 & 64.905 & 1.49 \\
\hline
\end{tabular}


A curva referente à pressão de alimentação de 10 m.c.a.,discrepante das demais na segunda região, mostra que o Ejetor 2, operando nessa condição, atingiu um limite de operação superior aos das demais pressões de alimentação, da ordem de 4,23 m.c.a. de pressão absoluta de sucção.

Para obtenção de maior vazão de sucção é, práticamente, indiferente adotar-se qualquer uma das pressões de alimentação de 20 a 50 m.c.a..

A Equação 1 não se ajustou adequadamente às curvas da Figura 20, conforme pode se comprovar com os coeficientes de determinação $\left(R^{2}\right)$ apresentados na Tabela 28. 


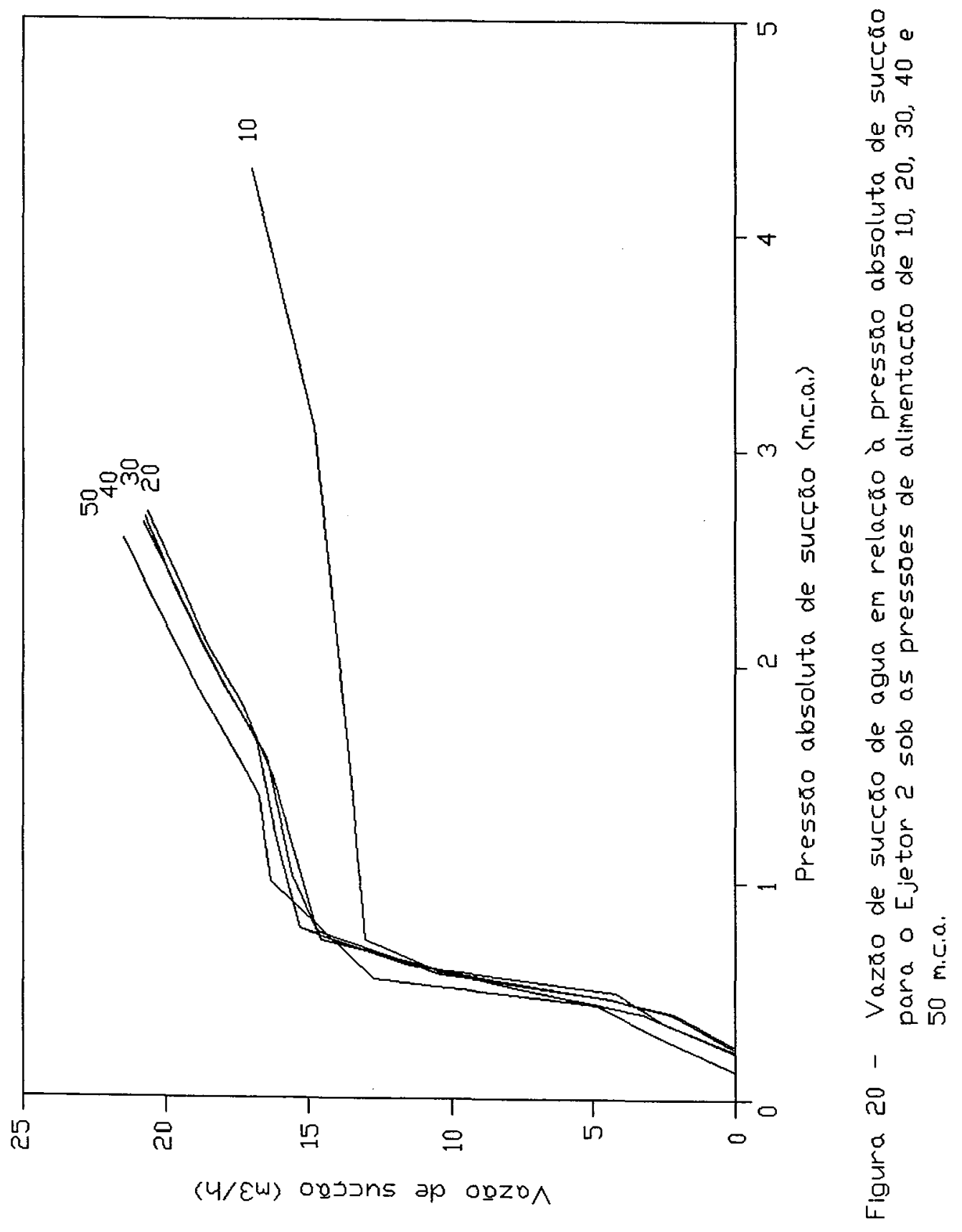


Tabela 28 - Valores dos parâmetros de ajuste da vazão de água succionada versus pressão de sucção para o Ejetor 2.

\begin{tabular}{|c|c|c|c||}
\hline $\begin{array}{c}\text { PRESSÃO DE } \\
\text { ALIMENTAÇÃO (m.c.a) }\end{array}$ & \multicolumn{1}{|l|}{$\mathrm{K}$} & $\mathrm{X}$ & $\mathrm{R}^{2}$ \\
\hline 10 & 34.312 & 0.597 & 0.615 \\
\hline 20 & 2.004 & 0.930 & 0.744 \\
\hline 30 & 2.642 & 0.903 & 0.758 \\
\hline 40 & 9.765 & 0.769 & 0.760 \\
\hline 50 & 3.607 & 0.881 & 0.815 \\
\hline
\end{tabular}

Com os resultados dos rendimentos que constam das Tabelas 23 a 27, calculados com a Equação 21, construíram-se as curvas da Figura 21.

Uma análise dessa figura mostra que, para todas as pressões de alimentação ensaiadas, o rendimento aumenta com a elevação da pressão absoluta de sucção. As curvas representantivas dos ensaios realizados sob as pressões de alimentação de 10 a 20 m.c.a.,mostram que o Ejetor 2, quando succionando água, apresenta os maiores rendimentos, ou seja de $4,08 \%$ e $3,97 \%$ respectivamente. Também é possível observar que os limites de operação desse ejetor, sob as pressões de alimentação de 20 a 50 m.c.a.,ocorrem, práticamente, para uma mesma pressão absoluta de sucção, em torno de 2,60 m.c.a.,e que é possível obterem-se aumentos no rendimento com a redução das pressões de alimentação de 50 para 20 m.c.a..

A curva representativa do rendimento para as condições de pressão de alimentação de 10 m.c.a, diverge acentuadamente das demais e mostra ainda que o Ejetor 2 tem um limite de operação próximo a 4,20 m.c.a.de pressão absoluta de suç̧ão.

Para todas as pressões de alimentação ensaiadas, o rendimento aumenta com a elevação da pressão de sucção. Quanto à pressão de alimentação, observa-se 


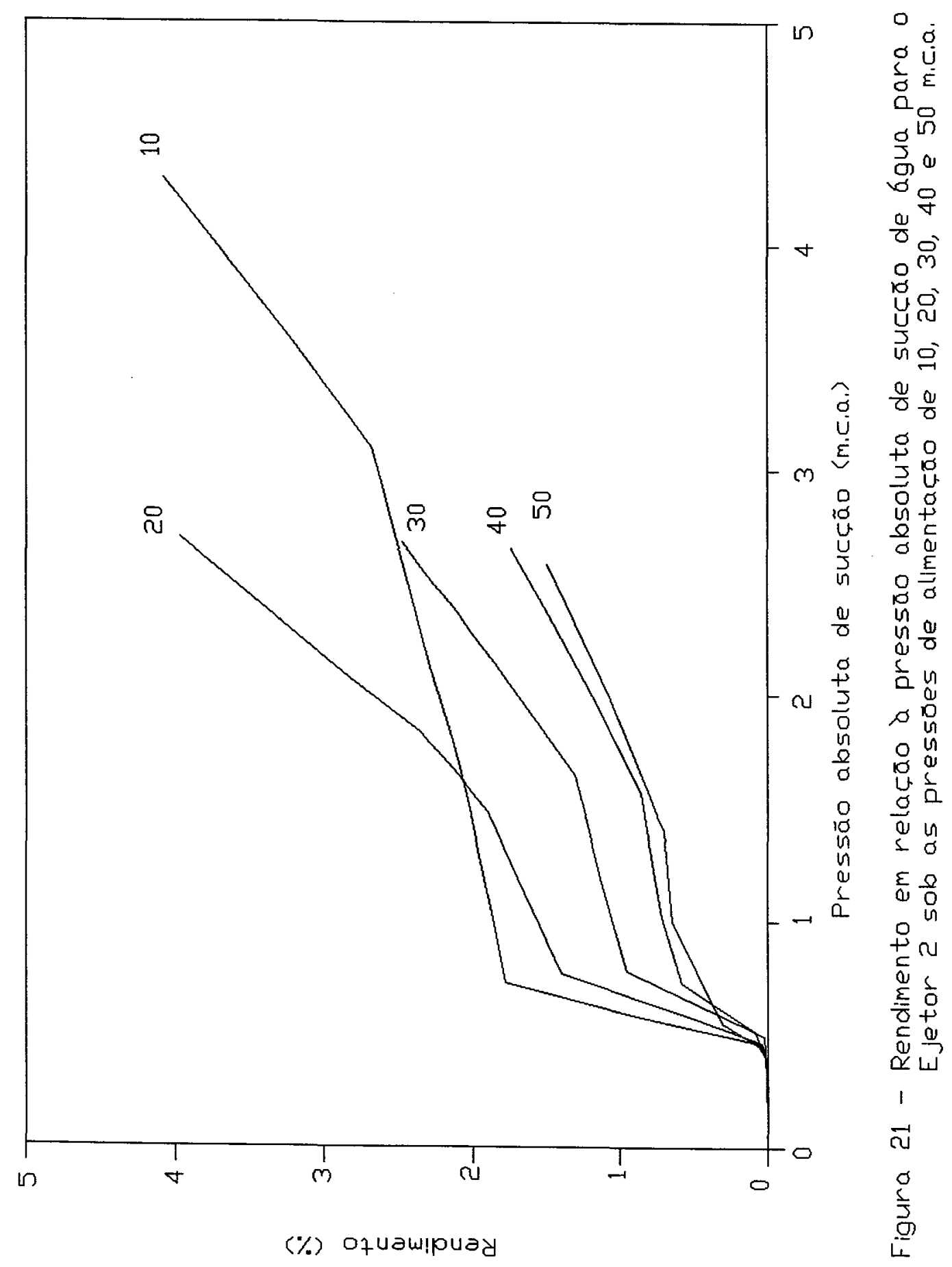


queda no rendimento com o aumento desta em toda a faixa de pressão ensaiada.

\subsection{Considerações gerais}

Para ambos os ejetores estudados, o melhor rendimento energético foi obtido para a sucção de ar, chegando a limites de $20,3 \%$ para o Ejetor 1 e $62,9 \%$ para o Ejetor 2. Para a sucção de água, os máximos rendimentos energéticos foram $11,1 \%$ e $12,9 \%$, respectivamente, para os Ejetores 1 e 2.

Existe um limite de pressão de alimentação, acima do qual pouco efeito se obtém na relação entre a vazão de sucção de água versus pressão de sucção. Este efeito foi notado a partir da pressão de 20 m.c.a. para ambos os ejetores. Isto permite que se recomende o emprego de pressões de alimentação de 10 e 20 m.c.a., quando se succiona água, pois as pressões superiores não aumentaram a capacidade de sucção e, ainda, conduziram a um baixo rendimento energético. 


\section{CONCLUSÕES}

Os resultados obtidos, devidamente discutidos, nos conduziram às seguintes conclusões, óbviamente válidas para os ejetores estudados, sob as condições e parâmetros experimentais:

- para ambos os ejetores, succionando água ou ar, a vazão de suç̧ão aumenta com a elevação da pressão absoluta de sucção;

- para ambos os ejetores, quando succionando ar, a vazão de suç̧ão aumenta com a elevação da pressão de alimentação;

- para ambos os ejetores, quando succionando água, elevações da pressão de alimentação acima de 20 m.c.a.,não melhoram a capacidade de sucção;

- para ambos os ejetores a curva que representa a relação vazão de sucção/pressão absoluta de sucção, pode ser calculada pela Equação 1, excessão feita ao Ejetor 2 succionando água;

- a Equação 21, proposta para calcular os rendimentos dos ejetores, mostrase adequada, sobretudo, indiferentemente da natureza do fluído succionado, isto é, seja ele ar ou água;

- os rendimentos dos ejetores, quando succionando ar, são superiores àqueles relativos à água;

- os rendimentos dos ejetores aumentam com a elevação da pressão absoluta de sucção, respeitados os seus limites de operação;

- ambos os ejetores apresentam um limite de operação, variável com a pressão de alimentação. 


\section{REFERÊNCIAS BIBLIOGRÁFICAS}

ADDISON, H. Tratado de Hidráulica Aplicada. Barcelona, 1959.704p.

CARLIER, M. Machines Hydrauliques. Paris. Imprimerie Louis-Jean, 1968.

CONTIN NETO, D. Levantamento da Curva Característica de Bocal Injetor para Turbinas Hidráulicas com Duto de Descarga Liso. São Carlos, 1973. 55p. (Mestrado - EESC-USP).

DENICULI, W. Desempenho de Turbina Hidráulica Tipo Hélice Associada a Bocal Injetor em Instalação de Baixa Queda. São Carlos, 1983. 156p. (Doutorado - EESC-USP).

DUGGINS, R. K. "Research Note: Conical Diffusers with Annular Injection", J. Mech. Engng. Sci, 17 (4):237-239, Aug. 1975.

GAVA, R. Contribuição ao Estudo dos Dispositivos Bocais Injetores Ampliadores de Queda com Jato Propulsor anular Externo. São Carlos, 1971. 95p. (Doutorado - EESC-USP).

KARASSIK, I. J.; KRUTZSCH, W. C.; FRASER, W. H.; MESSINA, J. P. Pump Handbook. New York (USA), McGraw-Hill Book Company, 1976. 
LENCASTRE, A. Hidráulica Geral. Lisboa, Edição Luso-Brasileira, 1983.

MACINTYRE, A.J. Bombas e Instalacões de Bombeamento. Ed. Guanabara Dois S/A, Rio de Janeiro, 1980.657p.

MARTINS, J. A. Bombas e Estações Elevatórias. São Paulo, Faculdade de Higiene e Saúde Pública. Escola Politécnica, 2a Edição, 1968, 383p.

MATAIX, C. Mecânica de Fluídos Y Maquinas Hidráulicas. Madrid, Ediciones Del Castillo, S.A., 1970.

NEKRASOV, B. Hidráulica. Ed. Mir, Moscou, 1968. 432p.

NICOLL, W. B. \& RAMAPRIAN, B. R.: "Performance of Conical Diffusers with Annular Injection at Inlet", J. Basic Engng, 92 (4): 827-835, 1970.

PETERS, H. "Bombas Injetores". In: Zambel, A.R. ed. Manual de Aparelhos de Bombeamento de Água. São Carlos, C. 1969. p. IX. 1-22.

TROSKOLANSKI, A. T. Hydrometry: theory and practice of hydraulic measurements. Oxford, Pergamon Press, 1960.

TROSKOLANSKI, A. T. Les Turbopompes: théorie, tracé et construction. Paris, Editions Ey Rolles, 1977.

VIEIRA, R.C.C. Pesquisa sobre a Aplicacão de Injetores a Turbinas Hidráulicas de Baixa Queda. São Carlos, 1966. 112p. (Cátedra - EESC-USP).

YASSUDA, E.R.; NOGAMI, P.S.; MONTRIGAUD R. Pocos Profundos. São Paulo, Faculdade de Higiene e Saúde Pública-USP, 1965. 